\title{
ARCHITECTURE OF A BENCH-TYPE CARBONATE LAKE MARGIN AND ITS RELATION TO FLUVIALLY DOMINATED DELTAS, LAS MINAS BASIN, UPPER MIOCENE, SPAIN
}

\author{
JOSE P. CALVO'1, DAVID GOMEZ-GRAS², ANA M. ALONSO-ZARZA, AND SERGIO JIMENEZ1 ${ }^{1}$ \\ ${ }^{I}$ Departamento de Petrología y Geoquímica, Facultad CC. Geológicas, Universidad Complutense, 28040 Madrid, Spain \\ e-mail: jpcalvo@eucmax.sim.ucm.es \\ ${ }^{2}$ Departamento de Geología, Facultad de Ciencias, Universidad Autónoma, 08193 Bellaterra, Barcelona, Spain
}

\begin{abstract}
The Upper Miocene stratigraphic succession of the Las Minas Basin, located at the external zone of the Betic Chain in SE Spain, preserves several examples of lake carbonate bench deposits. Excellent exposures of the carbonate benches allow detailed observation of the architecture of these sediments and provide new insights for the "steep-gradient bench margin-low energy" model proposed by Platt and Wright (1991). The lake carbonate benches developed in close association with fluvially dominated shallow deltas that exhibit typical Gilbert-type profiles. The delta sequences comprise bottomset prodelta marl facies, distal to proximal foreset facies, deposited mainly in a delta-front environment, and topset facies, the latter reflecting both subaqueous delta-front and subaerial delta-plain environments. The development of the carbonate benches was constrained by the convexupward morphology of the deltaic deposits, which led to the available accommodation space for the growth of the steep-gradient platforms. The benches display a progradational pattern characterized by sigmoid-oblique internal geometries and offlap upper boundary relationships, which suggests that the carbonate benches developed under slow though continuous lake-level rise. Both the dimensions of the benches and the dominant carbonate components (i.e., encrusted charophyte stems and calcified cyanobaterial remains), allow comparisons with the progradational marl benches recognized in modern temperate hardwater lakes. Accordingly, the case study presented here provides a good ancient sedimentary analog for low-energy lake carbonate benches. Moreover, the evolutionary trend inferred from the fossil example offers new insights into the depositional conditions of this type of sediment and allows recognition of the transitional pattern from bench to ramp carbonate lake margins.
\end{abstract}

\section{INTRODUCTION}

Facies models for recent and ancient carbonate lake systems have been refined considerably in the last two decades. The increasing available documentation on this topic allowed Platt and Wright (1991) to propose a twofold classification scheme for marginal lacustrine carbonate facies that is based on the morphology and on the wave energy conditions under which marginal facies accumulate. Accordingly, Platt and Wright (1991) subdivided carbonate lake margins into four types: (1) low-energy bench; (2) high-energy, wave-dominated bench; (3) low-energy ramp; and (4) highenergy, wave-dominated ramp. Examples of the four types of carbonate lake margins have been documented from both modern lakes and the fossil record. However, although some of the resulting facies models have been supported by abundant case studies, for example, the low-energy ramp type (Brown and Wilkinson 1981; Freytet and Plaziat 1982; Wells 1983; Freytet 1984; Cabrera et al. 1985; Alonso-Zarza et al. 1992; Platt and Wright 1992; Armenteros et al. 1997), documentation of the other types of lake margin is less common. In particular, models of the low-energy bench type are based on a few examples of modern North American lakes, i.e., Lake Littlefield (Murphy and Wilkinson 1980) and Sucker Lake (Treese and Wilkinson 1982), and from a single large-scale ancient example, the Lower
Cretaceous Peterson Limestone of Wyoming and Idaho (Glass and Wilkinson 1980). This paper attempts to refine the facies model for the lowenergy-bench type of carbonate lake margin by presenting a detailed study of Upper Miocene lacustrine carbonates in southeastern Spain. The excellent exposures of these carbonates allow the investigation of some aspects that are critical in evaluating the sedimentary model: (1) the relative depths of the lake floor ("basinal") and rimmed platform deposits; (2) the progradational pattern of the carbonate lake platform; (3) the distribution of carbonate facies within the bench lake margin; and, importantly, (4) the sedimentological and geomorphic factors accounting for the initial development and further growth of the carbonate benches. The case study is relevant in demonstrating that the architecture of the benches was controlled largely by the depositional pattern of terrigenous systems with which the carbonates are associated. This observation may aid further analysis of this type of carbonate lake margins elsewhere.

\section{GEOLOGICAL AND SEDIMENTOLOGICAL CONTEXT}

The lake carbonate bench deposits form the uppermost part of an approximately 500-m-thick succession of lacustrine sediments that accumulated in the Las Minas Basin throughout the Upper Vallesian and Turolian (Middle Tortonian and Messinian in the marine chronostratigraphic scale). The basin is located in the so-called Prebetic Zone of the Betic Chain, a major structural feature of southeastern Spain (Fig. 1A). The Las Minas Basin is the largest (ca. $160 \mathrm{~km}^{2}$ ) of several basins that formed in the area as a result of distensional tectonics during the Late Miocene (Bellanca et al. 1989; Calvo et al. 1998). The lacustrine Miocene deposits unconformably overlie Mesozoic terrigenous and carbonate formations, as well as Middle Miocene marine carbonate strata that either constitute the basin margins or are present as separate outcrops in inner parts of the basin (Fig. 1B).

The lowermost Tertiary continental deposits that crop out in the Las Minas Basin comprise turbidites related to resedimentation from shallow lake carbonate platforms (Elizaga 1994), which are followed by a rather monotonous succession of 2-3 m thick marlstone-carbonate cycles. At the top of lower third of the total section (Fig. 2 ), an episode of lake lowstand is marked by evaporite deposits, mainly gypsum and diagenetically formed sulfur (Calvo and Elizaga 1994). The evaporite beds are overlain by a thick package of alternating laminated carbonates and marls that are widespread in the northern part of the basin. The deepest lacustrine facies, composed of laminated marls containing abundant planktonic diatoms and siliceous sponge spicules, are found in that part of the basin, suggesting that it behaved as an asymmetrical trough at least during the final stages of the lake (Calvo and Elizaga 1994). Lamproitic volcanic rocks, dated at $5.7 \pm 0.3 \mathrm{Ma}$ by Bellon et al. (1980), are present as small isolated outcrops in the central part of the basin (Fig. 1B). Seismic activity associated with the volcanism caused breakdown of the older lacustrine platforms (Calvo and Elizaga 1987), resulting in the formation of scars and slumps at several scales. A slump deposit formed of a set, up to $40 \mathrm{~m}$ thick, of contorted and fractured marl and limestone beds (Fig. 2) can be traced across most of the basin. The resedimented deposits are covered by a monotonous succession of alternating diatomaceous marlstone and limestone deposited at moderate depth in open lake areas (Elizaga 1994). The Miocene section is capped by a mixed siliciclastic-carbonate stratigraphic unit that is restricted to the northern part of the basin, along the footwall of a major fault bounding the Sierra de los Donceles (Fig. 1B).

The mixed siliciclastic-carbonate unit is formed of mudstone, sandstone, and lacustrine carbonate deposits that are especially well exposed along the Rambla del Saltador (Fig. 3), a 4-km-long creek incised parallel to the strike of the Miocene beds. Several smaller creeks cut these beds normal to strike so that the outcrops allow partial three-dimensional observation of the siliciclastic and carbonate se- 

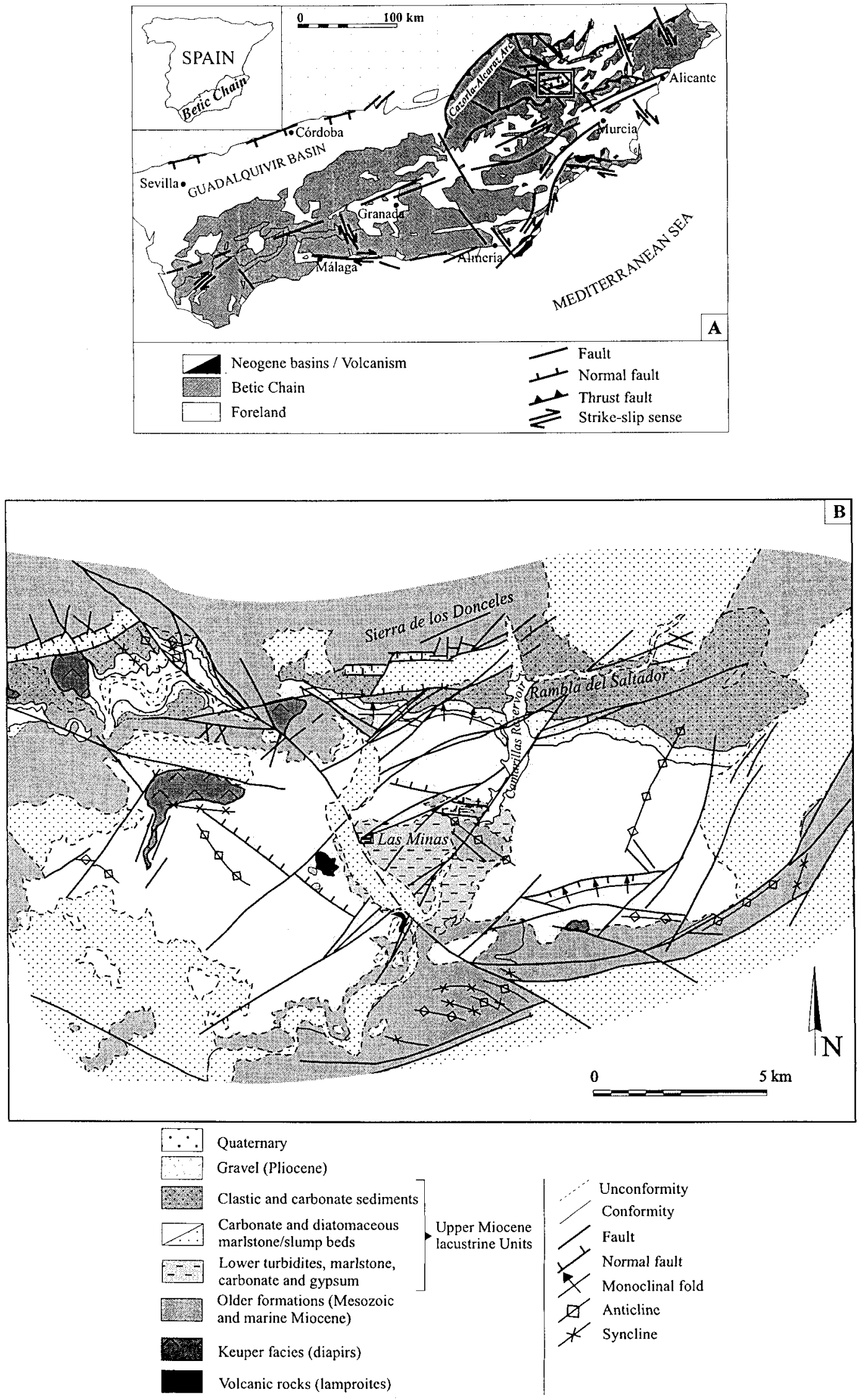

FIg. 1.-Location map for the study area. A) Structural framework of the Betic Range in SE Spain with the location of the Las Minas Basin (rectangle); B) Geological sketch map of the Las Minas Basin. The Rambla del Saltador area lies at the upper right side of the map. 


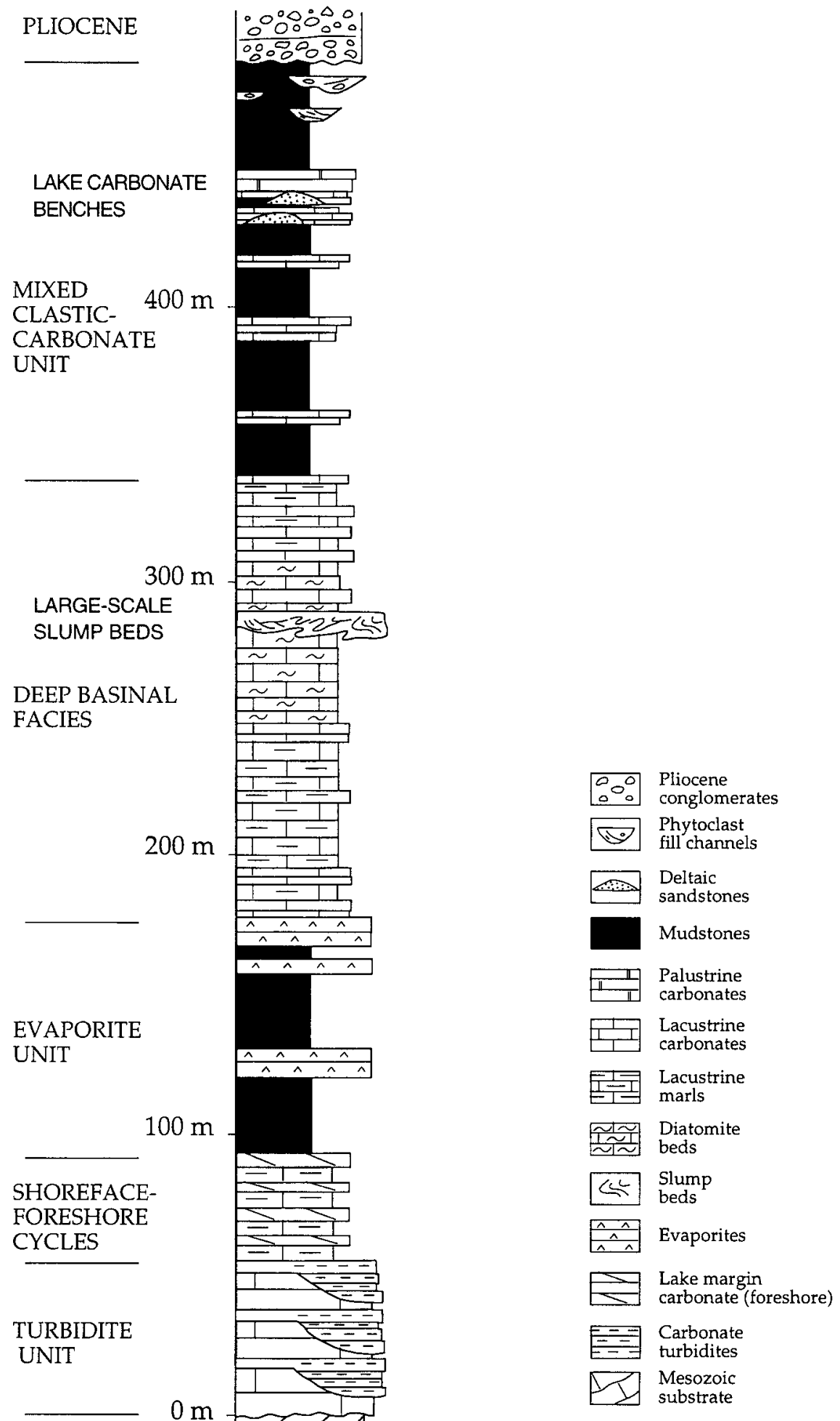

FIG. 2.-Simplified summary stratigraphic column of the Upper Miocene lacustrine deposits of the Las Minas Basin showing the stratigraphic position of a main episode of slump formation (see text) and location of the lake carbonate benches described in this study. quences. The total thickness of the siliciclastic-carbonate unit reaches $150 \mathrm{~m}$. The lower part of the succession, which is not exposed in the eastern side of the area, comprises brownish sandy mudstones in which three main tabular white marlstone and limestone beds are intercalated. The uppermost part of the succession, exposed along the Rambla del Saltador, consists of two superposed packages of sandstone bodies with associated brownish mudstone that are covered by carbonate beds whose geometries are clearly influenced by those of the sandstones. The total thickness of these two sediment packages is about $25 \mathrm{~m}$. The upper package, which is the focus of this study, is overlain by broadly tabular carbonate beds with intervening organicrich layers. These extend both north and south of the creek and are, in turn, covered by reddish mudstone containing sandfill channels. The top of the Miocene succession is capped unconformably by Pliocene fluvial gravels.

This paper deals mainly with the terrigenous and carbonate deposits that are located toward the upper part of the Rambla del Saltador section. Elizaga (1994) was 


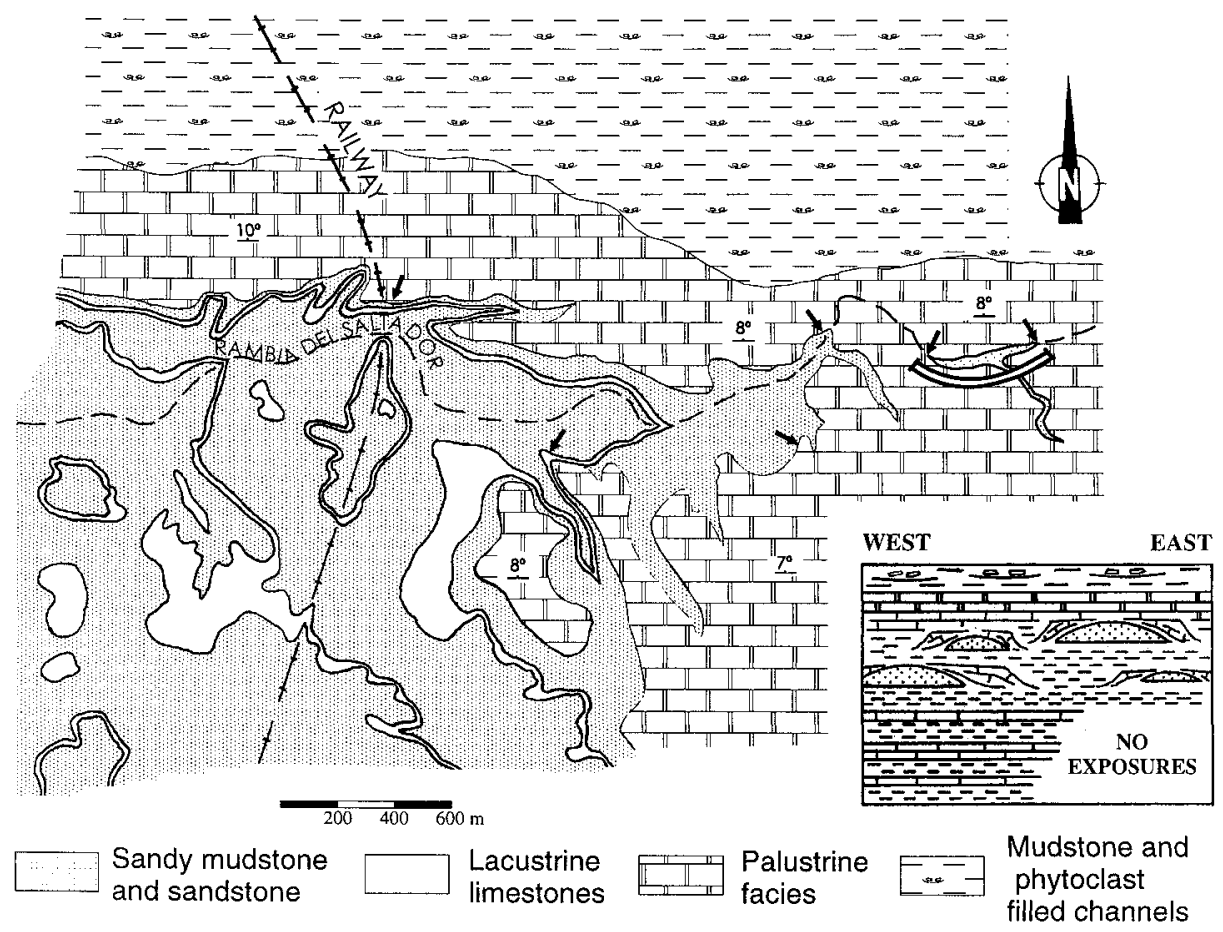

FIG. 3.-Detailed geological map of the Rambla del Saltador area. The line drawn at right of the map indicates the location of the cross section shown in Figure 4. Arrows indicate the location of outcrops of well-exposed carbonate benches in the area. The stratigraphic framework of the Upper Miocene deposits in the area is summarized in the rectangle. the first to recognize the complex geometric relationships between the sandstone bodies, which he interpreted as Gilbert-type delta deposits, and the associated lacustrine limestones. Bellanca et al. (1995) provided a sedimentological and geochemical approach for differentiating lacustrine and palustrine carbonates in the area. They described a lower member composed of carbonate beds deposited in a platform bench-margin lake environment and an upper member formed of carbonates interbedded with organic-rich marlstones that they interpreted as palustrine deposits. The recognition of the bench-margin lake carbonate facies by Bellanca et al. (1995) served as the starting point for the analysis of their characteristics and pattern of formation that we present in this paper.

\section{FACIES DISTRIBUTION}

An east-west cross section (Fig. 4A, B) was studied in the eastern part of the Rambla del Saltador (Fig. 3) in order to examine the distribution and stratigraphic relationships between the terrigenous and the carbonate deposits. The section (Fig. 3 ), which is $400 \mathrm{~m}$ long, is traced perpendicular to the main direction of the terrigenous depositional system as deduced from paleocurrent measurements in the sandstones. Paleocurrent directions were measured on both the dip planes of foresets (Figs. 5, 6) and using current ripples (see facies description below). Both indicate clearly that the direction of flow was south to north in this part of the basin. The easternmost side of the section (Fig. 4A) shows carbonate beds that dip at up to $28^{\circ}$ toward the east (Fig. 7). The thickness of these carbonate beds is seen to decrease in proximity to the sandstone bodies. Both the sandstones and the mudstones display a complex arrangement of cross-bedded units and channelized forms that can be followed laterally all along the lower part of the section. These in turn are capped by crudely tabular carbonate beds. The westernmost side of the section (Fig. 4B) also includes sloping carbonate beds similar to those observed on the eastern side, but with an opposite dip direction.

Bearing in mind the south-to-north direction of the flow, which is almost perpendicular to the two-dimensional section, the carbonate beds form benches that developed laterally to the main direction of terrigenous supply. Moreover, northwarddipping carbonate beds can be recognized just in front of the outcrop described, which provides evidence that the carbonate benches developed as a halo surrounding the terrigenous system. Other examples of these stratigraphic and depositional relationships between the terrigenous and carbonate deposits have been recognized in several places throughout the Rambla del Saltador area (Fig. 3); they will be grouped with the example described in order to present a general sedimentary model for these deposits.

\section{FACIES DESCRIPTION AND INTERPRETATION}

The main sedimentary features of the terrigenous and carbonate deposits present in the Rambla del Saltador are summarized in Table 1. The clastic units show typical bottomset, foreset, and topset depositional geometries of lake-margin deltas as documented in the classical model of Gilbert (1885). Sedimentary logs that show the vertical and lateral relationships of these lithofacies are presented in Figure 6.

\section{Bottomset Deposits}

Description.-These deposits crop out with a thickness of $1 \mathrm{~m}$ at the base of the section. They consist of massive to crudely laminated, grayish-green marlstone beds with varied carbonate content. Stratification of the marls results mainly from differences in color, although it is locally marked by a higher abundance of gastropod shells and bioturbation traces. The degree of bioturbation is high in some beds. Thin carbonate and siliciclastic silty layers with normal grading are locally interbedded with the marlstone.

Interpretation.-The marlstone with intercalated silty layers is interpreted to result from slow deposition of suspended sediment under the influence of an active delta leading to the formation of deltaic bottomset deposits transitional to basinal sediments (prodelta environment). The bottomset silty layers may represent deposition by low-density turbidity currents (cf. Lowe 1982). Bioturbation of the bottomset beds indicates reworking of the sediment by organisms during periods of low sediment discharge.

\section{Foreset Deposits}

Description.-This facies association comprises both sandstone and silty mudstone that form steeply inclined $\left(30-35^{\circ}\right)$, accretionary beds (Fig. 5) that dip toward the lake area. These beds are up to $4 \mathrm{~m}$ thick (Fig. 6). Individual foreset beds show typical downslope fining and decreasing dip along the foreset slope. Some foreset beds have a sigmoidal geometry. Two distinct lithofacies can be recognized in the foreset deposits: (1) The updip part of the foreset beds, up to $2 \mathrm{~m}$ thick, consists of very well-sorted, fine-to medium-grained sandstones with planar lamination and climbing ripples; individual sandstone beds usually exhibit normal grading, although inverse grading is present locally; cross-bedding, scour-and-fill structures, ripple marks, and erosional surfaces between the beds are also present. (2) The downdip part of the foreset beds, with an average dip of $24^{\circ}$, comprises dip-oriented climbingrippled sandstone intercalated within yellow-brown, horizontally laminated silty mudstone; this laminated mudstone, up $0.7 \mathrm{~m}$ thick, typically forms superposed graded layers, $2.5-3 \mathrm{~cm}$ thick, whose basal part is locally formed of very fine- 
J.P. CALVO ET AL.
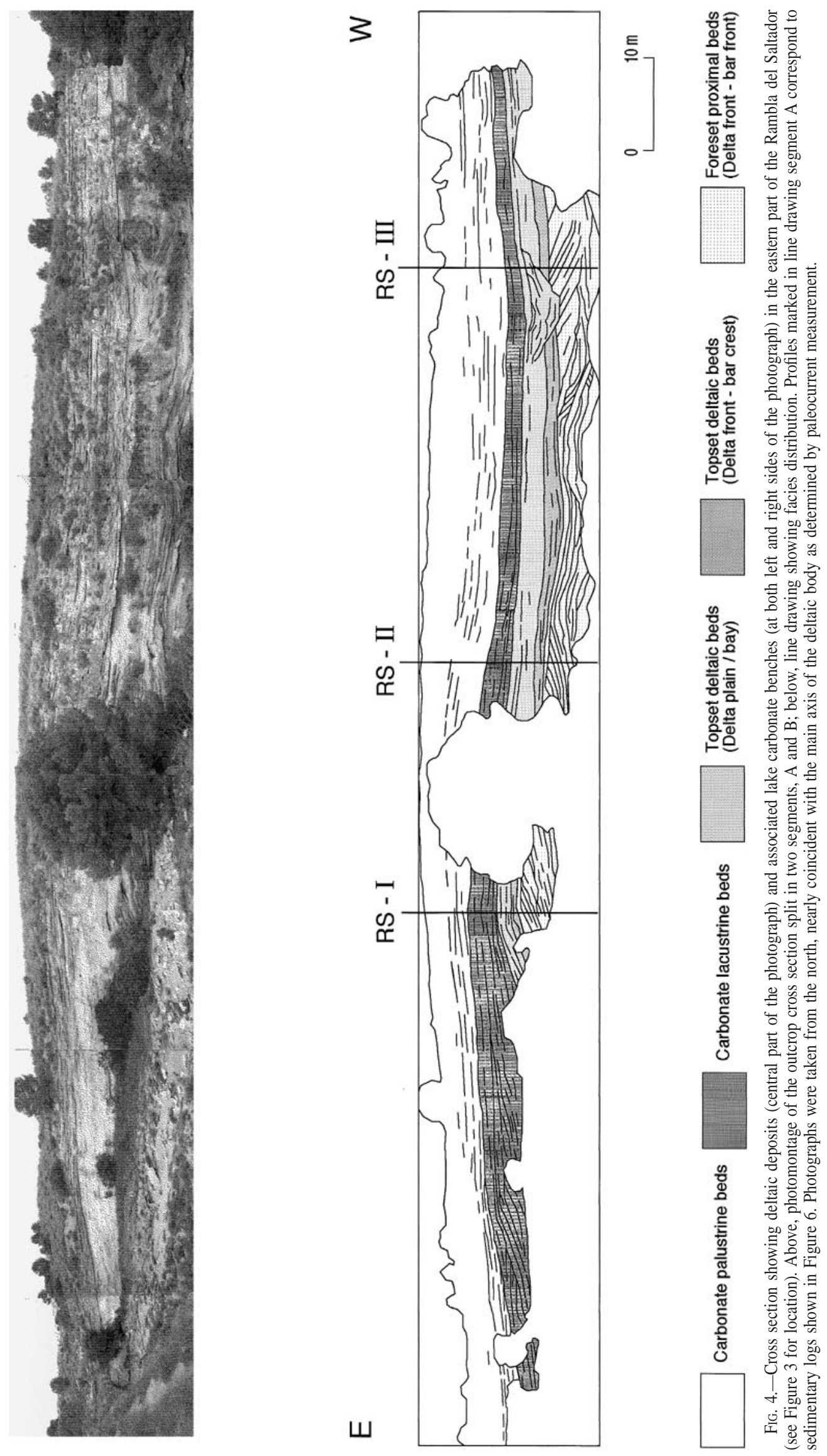

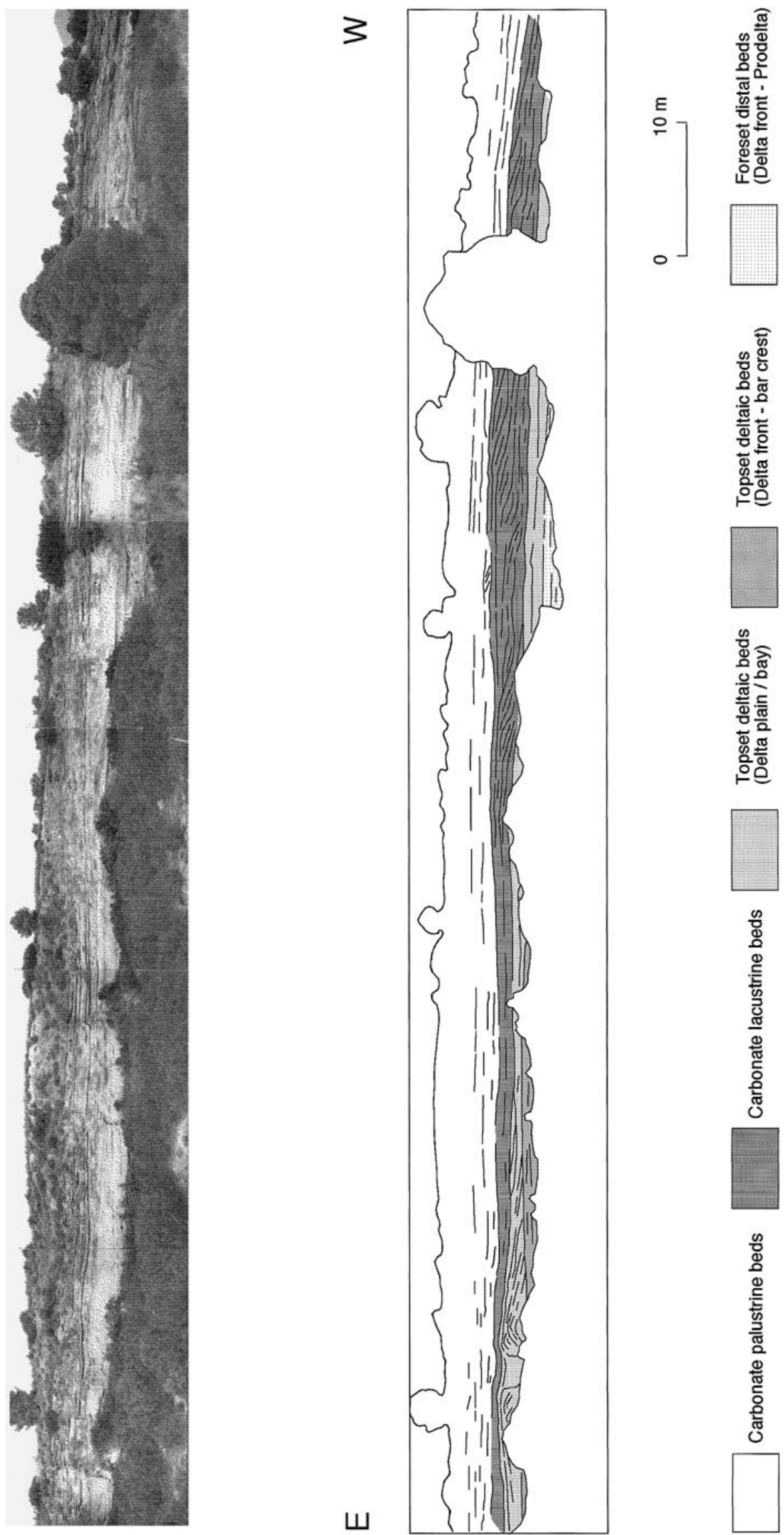

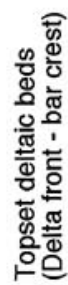
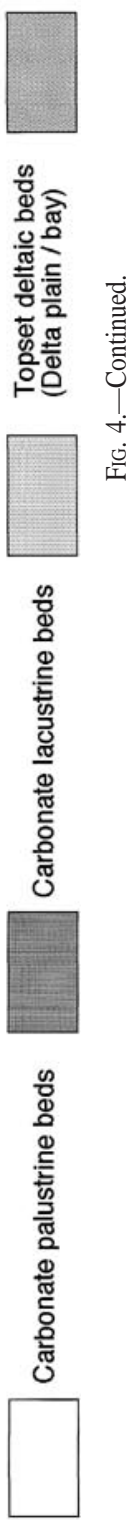


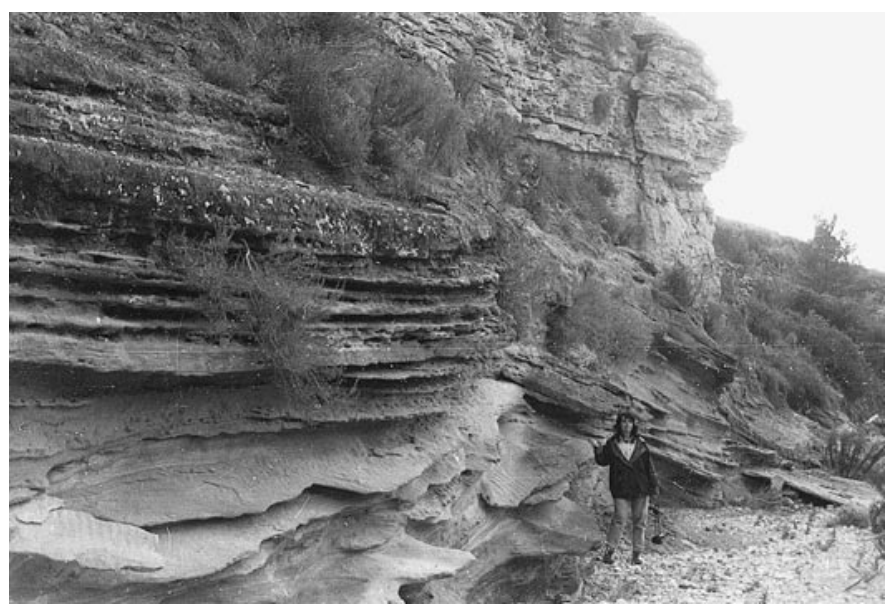

FIg. 5.-Outcrop view of the deltaic facies in Rambla del Saltador. Steeply inclined $\left(30-35^{\circ}\right)$ sandstone beds correspond to foreset beds characteristic of a Gilberttype delta profile. North is located toward the right of the photograph. Horizontal beds in the middle part of the photograph are interpreted as topset deltaic deposits. The uppermost deposits in the photograph correspond to shallow lake/palustrine carbonate beds. Person is $1.70 \mathrm{~m}$ tall.

grained sandstone. Intercalations of white, more calcareous beds are present within the yellow-brown mudstone deposits.

Composite foreset sequences are formed of numerous imbricated foresets that are separated by unconformities or reactivation surfaces. These surfaces are usually draped by thin silt and/or clay bottomset deposits that pinch out landward. Packages of delta foreset beds are separated by large curved scour surfaces.

Interpretation.-The planar cross-stratified sandstones are interpreted as steep avalanche sets, characteristic of proximal foresets. Changes in location of foreset building are marked by large curved scour surfaces that separate packages of foreset beds. These sediments represent the sloping, lakeward margin (bar front) of an advancing subaqueous delta-front environment (Orton and Reading 1993). In this setting, progradation is controlled by bedload deposition from turbidity currents flowing down the avalanche slope during episodic flood events. In contrast, the climbing-rippled sandstone and the silty mudstone beds are interpreted as distal foreset deposits in which climbing ripples and graded silt layers represent waningflow sequences. Distally, the silty mudstone beds interfinger with the bottomset deposits. Interbedding of silty mudstone and carbonate may indicate episodic stabilization of the clastic input and further precipitation of the lake carbonate directly on the delta-front sediments.

\section{Topset Deposits}

Description.-The topset deposits comprise two distinctive facies associations reaching $5.5 \mathrm{~m}$ in maximum thickness (Fig. 6). The lower part of the topset deposits consists of a 2.5 -m-thick package of multistory, moderately sorted, coarse- to medium-grained sandstone beds with intervening erosional contacts. The internal structure of the sandstone beds is characterized by planar and trough cross-stratification, some beds showing microconglomerate lags where phytoclasts and mud chips are prominent constituents. Where not incised by the overlying sandstone, the beds are topped by ripple-laminated finer-grained sandstone, locally with wave ripples. These lower topset deposits are separated from the foreset beds by a subhorizontal erosional surface, although near the slope break the topset beds conformably overlie the dipping foresets.

The upper part of the topset deposits is predominantly finer grained and consists of sandy silt, silty marlstone, and calcareous marlstone containing abundant gastropod remains. Several facies associations are recognized within these deposits:

Channel-Fill Sediments: The paleochannels are 2-3 m thick and 8-10 m wide. The steep channel sides are symmetrical, and the base cuts sharply into the underlying sediments. Sediment fill consists of coarse to fine, even silty sand that grades upward into silty mudstone. The lowest part of the channel fill is formed of a microconglomeratic lag containing abundant phytoclasts and carbonized wood fragments. Two main sand-filled channels are present in the section (Fig. 4A, B). The channel at the west side of the section shows a lower microconglomerate lag overlain by trough cross-bedded, coarse-grained sandstone that passes upward into thinner sets of finer-grained ripple cross-laminated sandstone. The total thickness of the channel fill is $3.1 \mathrm{~m}$. The channel at the east side of the section shows a different infill sequence dominated by finer-grained sediment. The overall internal structure of the channel is markedly concave upward, with a total thickness of $3.8 \mathrm{~m}$. The lower part of the infill consists of silt-poor, cross-bedded sandstone that grades upward into silty sand displaying small-scale cross-bedding. Most of the channel fill ( $2.1 \mathrm{~m})$ consists of laminated to massive silty marlstone beds, some of which extend laterally away from the channelized body.

Levee Sediments: These deposits form clastic wedges with a characteristic triangular cross section. They are up to $3.7 \mathrm{~m}$ thick adjacent to the channels, and can be followed for about $20 \mathrm{~m}$, thinning rapidly away from the channel. The sediments consist of well-bedded, horizontally laminated to ripple cross-laminated siltstone and marlstone with intervening sandstone beds displaying small-scale cross-bedding and local climbing ripples. The sediment is locally reddened and contains root traces and scattered plant debris. The levee deposits downlap the upper topset beds and grade laterally into the deposits that accumulated in interdistributary troughs.

Interdistributary Trough/Open Bay Sediments: These deposits, up to $1 \mathrm{~m}$ thick, consist of massive to horizontally laminated silty marlstone interlayered with finegrained sandstone, sandy siltstone, and argillaceous marlstone. The sandstone units typically display a lenticular geometry, and reach up to $30 \mathrm{~cm}$ in height and 2-3 m in length. The internal structure of the sandstone bodies is characterized by crossbedding that grades laterally into finer-grained deposits. The geometric relationship of these deposits with other lithofacies associations of the topset deposits shows that the interdistributary trough sediments grade laterally into the adjacent levee sediments, but in the vicinity of the distributary mouths (open bays) they grade downward into lake-bottom sediments. In this situation, both lenticular and wave-ripple bedding are common in the fine-grained sandstone and siltstone beds.

Interpretation.-The topset deposits comprise a complex lithofacies association with significant changes from bottom to top. The lower sediment package $(\sim 2.5 \mathrm{~m}$ thick), comprising multistory, erosional sandstone beds with planar and trough crossstratification, is interpreted as upper delta-front deposits which accumulated mainly under the influence of fluvial discharge and which represent the subaqueous part of the topset deposits (Coleman and Gagliano 1965). As a whole, the lower part of the topset sediments and underlying foreset and bottomset deposits constitute a rivermouth bar showing a Gilbert-type profile that was deposited in a delta-front environment (Wright 1977). As observed in recent deltaic environments, the narrow river-mouth bars typically show a lunate shape in plan view (bar crests), and their deposition is related to inertia-dominated effluent diffusion (Wright 1977). The upper topset deposits, composed of channel-fill sediments, levee deposits, and finergrained sediments that accumulated in interdistributary troughs and open bay settings, represent a delta-plain environment (Fisk 1961; Coleman and Gagliano 1965; Donaldson et al. 1970; Gould 1970). The channel deposits are interpreted as the products of straight and stable distributaries whose energy decreased progressively, resulting in infill of the channels with fining-upward sequences. The dominant sandfill observed in one of the channels is indicative of active infilling related to decreasing flow upstream, probably due to progressive abandonment of the channel. On the other hand, the predominance of finer-grained sandstone and mudstone in the other channel suggests that the channel was actively incised but suddenly abandoned, the channel course being filled later by overbank flows from adjacent channels. Thus, the resulting fill sequence is one that could be expected from passive superposition of clay plugs. These channels are similar to those described as type C feeder systems by Postma $(1990,1995)$, although they could also represent an intermediate case between his type $\mathrm{C}$ and type $\mathrm{D}$ feeder systems. The channel architecture reflects moderate-gradient sandy alluvial systems of closely spaced, but relatively stable, channels acting as a line source characterized by fixed points of sediment supply. Orton and Reading (1993) described similar channels in sandy, mixed-load delta plains that were incised by straight or meandering channels with clay-consolidated channel banks.

The levee sediments were deposited subaerially when flood waters escaped from the channels onto overbank areas. A zonation of coarser-grained accumulations close to the channels and finer-grained sediment deposited farther out in the interdistributary troughs is recognized. In the latter subenvironment, fine-grained sandstone accumulated as shallow-water distributary crevasse deposits that incised the levees in episodic floods. Most sediment settled from suspension, so that the most distal deposits are finer-grained and covered the floor of the interdistributary troughs and bays.

\section{Carbonate Bench Deposits}

Description.-At both the eastern and western sides of the cross section (Fig. 4), the deltaic terrigenous facies are covered by carbonate sediments that display an internal stratal pattern consisting of inclined, laterally prograding carbonate beds (i.e., clinoforms; Fig. 7). Three clinoform sets, outlined by changes in inclination of the sloping beds, are recognized throughout the carbonate bench deposits. The resulting picture is that of a sigmoid-oblique progradational pattern of carbonate strata (Bosellini 1984), where horizontal to gently dipping, tabular platform carbonate beds pass laterally into sloping carbonate beds whose inclination decreases progressively 
RS - III

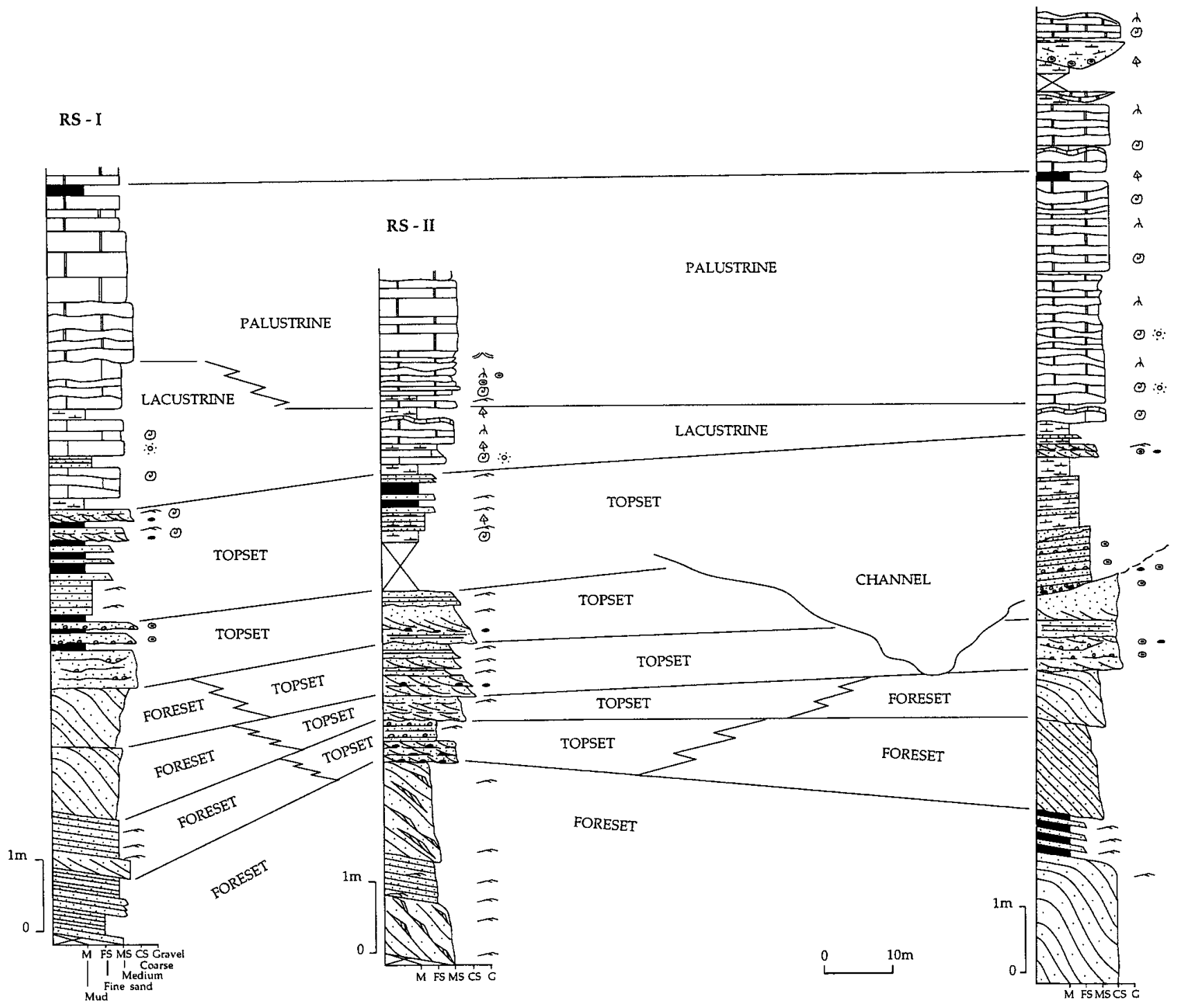

Lacustrine carbonates
Mudstones

(1) Gastropod shells
4 Plant debris
๑ Phytoclasts
- Intraclasts
h Root tubules
$\therefore$ o: Charophytes

\begin{tabular}{|c|c|}
\hline$=$ & Ripple cross-lamination \\
\hline 分 & Wave ripples \\
\hline 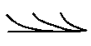 & Cross-bedding \\
\hline & Planar lamination \\
\hline & Lateral facies change \\
\hline & Pebbles \\
\hline
\end{tabular}

FIg. 6.-Sedimentary logs of deltaic lithofacies and overlying lacustrine and palustrine deposits. See location of the sections in Figure 4A.

toward the toe of slope. The lower clinoform set directly overlies topset marlstone deposits. The geometry of the clinoform set is slightly sigmoidal, with a maximum observed thickness of $3 \mathrm{~m}$. The internal structure of this set is characterized by decimeter-thick, marly carbonate beds, whose dip angles decrease gently from bottom to top. The convex-upward morphology of the set of carbonate strata is marked by a relatively rapid change in slope from $7^{\circ}$ to $19^{\circ}$ (Fig. 7). The upper boundary of this clinoform set displays slight truncations at the ends of the carbonate beds, whereas the lower boundary is characterized by the flattening out of the beds. The second clinoform set has a better defined sigmoidal geometry. The maximum thickness of this set is $1.3 \mathrm{~m}$, thinning toward both the platform and the lower slope 

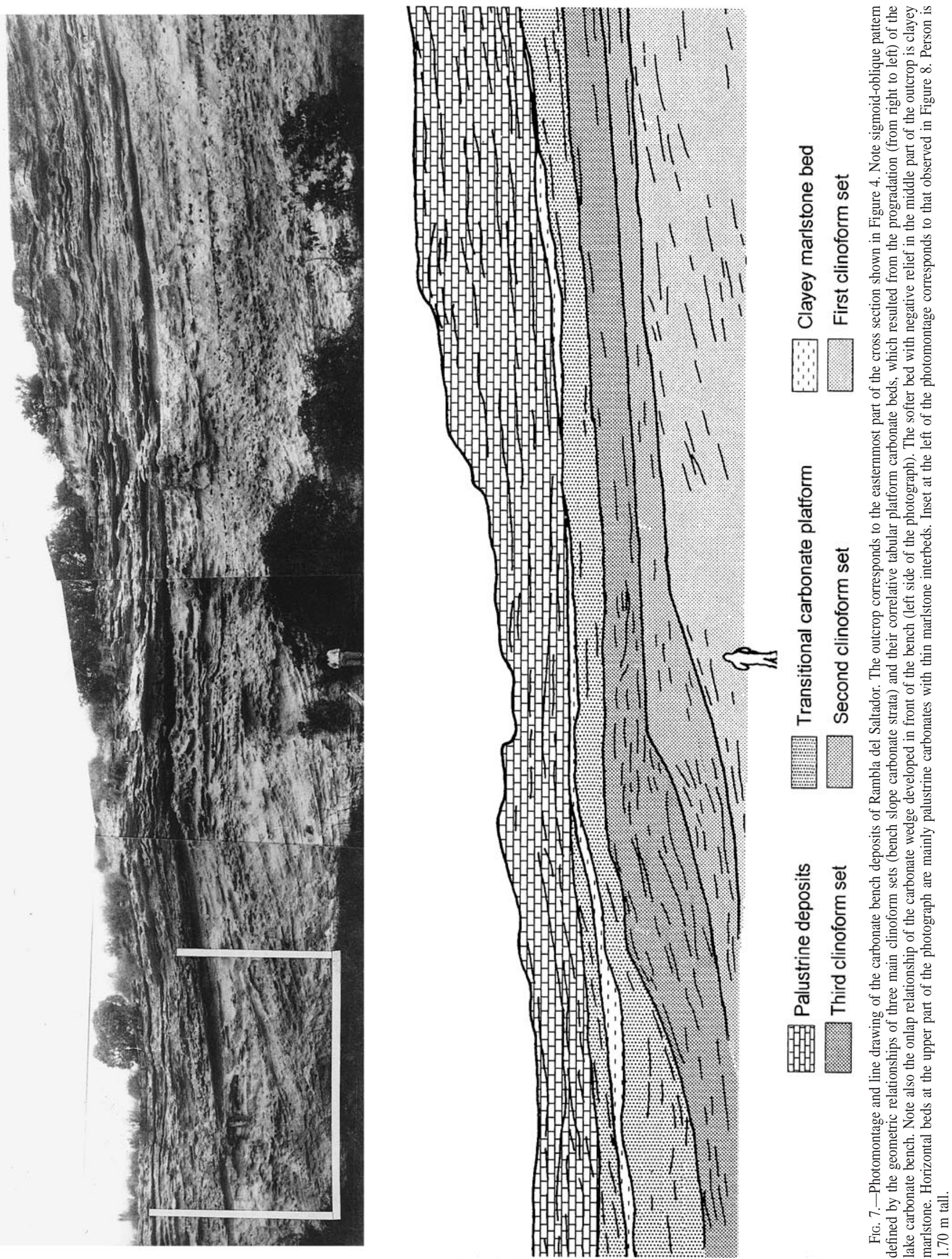
TABLE 1.-Summary of sedimentary facies descriptions and depositional systems of the lake carbonate benches and associated deltas in Rambla del Saltador.

\begin{tabular}{|c|c|c|}
\hline Lithofacies Association & Sedimentary Features & Depositional System \\
\hline $\begin{array}{l}\text { Massive marlstone with intercalated thin silt- } \\
\text { stone beds. }\end{array}$ & $\begin{array}{l}\text { Structureless to irregular lamination defined by changes in color, degree of bioturbation, and } \\
\text { abundance of gastropod shells. Interbedded siltstone (turbidites) shows normal grading. }\end{array}$ & Prodelta—bottomset deposits. \\
\hline $\begin{array}{l}\text { Fine- to medium-grained sandstone and lami- } \\
\text { nated silty mudstone. }\end{array}$ & $\begin{array}{l}\text { Well-sorted foreset sandstone beds exhibiting planar and climbing-rippled lamination with } \\
\text { normal grading. Local scour-and-fill and erosional surfaces. Laminated mudstone formed } \\
\text { of stacked cm-thick, normally graded siltstone layers. }\end{array}$ & Subaqueous delta front-proximal to distal foreset deposits. \\
\hline $\begin{array}{l}\text { Coarse- to medium-grained sandstone and mi- } \\
\text { croconglomerate. }\end{array}$ & $\begin{array}{l}\text { Multistory planar and trough cross-stratified sandstone with microconglomerate lags. Mud } \\
\text { chips and phytoclasts. Abundant erosional surfaces. }\end{array}$ & Upper delta front—subaqueous topset deposits. \\
\hline $\begin{array}{l}\text { Coarse- to very fine-grained sandstone and } \\
\text { silty mudstone infilling channels. }\end{array}$ & $\begin{array}{l}\text { Microconglomerate lags. Trough cross-stratification and ripple cross-stratification. Typical fin- } \\
\text { ing-upward channel-fill sequences. }\end{array}$ & Delta plain—active and/or abandoned channels. \\
\hline $\begin{array}{l}\text { Silstone and mudstone with interbedded sand- } \\
\text { stone. }\end{array}$ & $\begin{array}{l}\text { Well-bedded, horizontally to ripple cross-laminated siltstone and marlstone. Sandstone shows } \\
\text { cross-bedding and occasional climbing ripples. Root traces }\end{array}$ & Delta plain—levee deposits. \\
\hline $\begin{array}{l}\text { Silty marlstone with interbedded sandstone and } \\
\text { silty sand. }\end{array}$ & $\begin{array}{l}\text { Cross-bedded sandstone bodies with lens-like geometries. Massive to flat-laminated silty } \\
\text { marlstone. }\end{array}$ & $\begin{array}{l}\text { Delta-plain deposits accumulated in interdistributary } \\
\text { troughs and bays. }\end{array}$ \\
\hline \multirow[t]{2}{*}{$\begin{array}{l}\text { Skeletal to micrite-rich limestone (marl lake } \\
\text { sediments). }\end{array}$} & $\begin{array}{l}\text { Tabular, flat to gently dipping limestone beds. Wackestone formed mainly of encrusted char- } \\
\text { ophyte stems and calcified cyanobacterial clusters. }\end{array}$ & Lake bench platform. \\
\hline & $\begin{array}{l}\text { Dipping limestone beds (clinoforms) with angles ranging from } 7^{\circ} \text { to } 28^{\circ} \text {. Wackestone and } \\
\text { packstone formed mainly of reworked skeletal fragments. }\end{array}$ & Lake bench slope. \\
\hline Calcareous marlstone. & $\begin{array}{l}\text { Well-bedded tabular marlstone. Wackestone to mudstone with scattered ostracod shells and } \\
\text { gastropods. Diatom frustules within the groundmass. }\end{array}$ & Basinal lake deposits. \\
\hline $\begin{array}{l}\text { Limestone, organic-rich marlstone, and sandfill } \\
\text { channels. }\end{array}$ & $\begin{array}{l}\text { Massive to laminated tabular limestone beds. Local carbonate mounds. Typical freshwater } \\
\text { biota (gastropods, ostracods, charophytes). Oncoid and intraclast-fill channels. Dark organ- } \\
\text { ic-rich marlstone with abundant gastropods. Sand-fill channels display lateral accretion. }\end{array}$ & $\begin{array}{l}\text { Carbonate shallow lake undergoing periodic lake-level fluc- } \\
\text { tuation (palustrine conditions). Marshes. }\end{array}$ \\
\hline
\end{tabular}

zones. The angles of the clinoforms downslope conform broadly to those determined in the underlying clinoforms, while the carbonate beds at the edge of the sigmoid dip at up to $23^{\circ}$. The third clinoform set has a similar geometry and a maximum thickness of $1.8 \mathrm{~m}$. The well-bedded platform carbonate beds that are related laterally to these clinoforms conformably overlie those of the second clinoform set. Carbonate beds at the edge of the sigmoid dip at up to $28^{\circ}$.

The outer surface of the third clinoform set is covered by onlapping tabular carbonate beds (Fig. 8) that pass progressively upward into tangential beds draping the upper part of the clinoform surface and conformably overlie older platform carbonates. The upper surface of the carbonate deposits is veneered by a light green, clayey marlstone bed that is seen to cover the carbonate irregularly (Figs. 7, 8). The clayey marlstone bed dips at approximately $11^{\circ}$. It is overlain, in turn, by a wedge of carbonate beds that thicken in the same direction as the complete package of clinoforms. A 2-m-thick package of palustrine carbonates, comprising tabular, commonly root-bioturbated carbonate beds, carbonate mounds, oncoid- and intraclastfilled channels, and phytoclast shoals (Bellanca et al. 1995), overlies the section. These carbonates are horizontally stratified, in contrast to the underlying bench carbonate deposits.

The total thickness of the bench platform and slope carbonate deposits in the measured outcrop is up to $5.5 \mathrm{~m}$ and the length of the section is $\sim 70 \mathrm{~m}$ (Fig. 4). There is a variation in thickness from $2.6 \mathrm{~m}$ of tabular, platform carbonate beds superimposed on the deltaic facies to maximum vertical thickness of $5.5 \mathrm{~m}$ in the

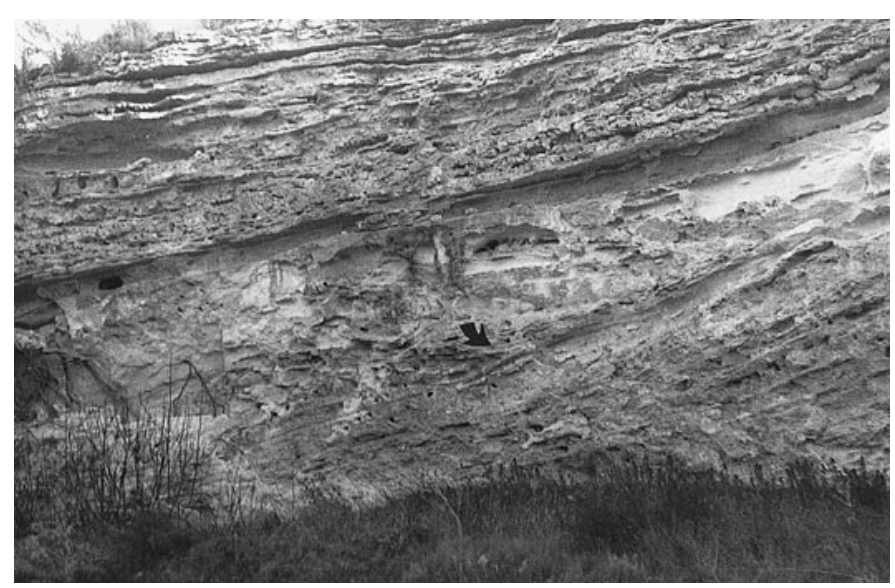

FIG. 8.-Close-up view of the onlap relationships (arrow) between flat-lying lacustrine carbonate beds and the outer surface of the clinoform set that corresponds to the termination of the carbonate bench. Note veneering of the carbonate beds upward onto the clinoform surface. A clayey marlstone bed (negative relief) truncates the carbonate deposits and is in turn succeeded by conformable, gently dipping carbonate that forms a fan of beds below horizontal palustrine carbonate deposits. The height of the outcrop is $5.30 \mathrm{~m}$. part of the section where the progradational carbonate sigmoids are present. The thickness of the platform carbonates, where they directly overlie the core of riverdominated delta deposits, is reduced to $1 \mathrm{~m}$. The carbonate beds at these sites display channel geometries and abundant erosional surfaces.

The bench platform deposits consist of weakly laminated, white, soft to indurated beds of biomicrite (mainly wackestone) in which calcified cyanobacterial clusters, encrusted charophyte stems and gyrogonites, gastropods, and ostracod shells are the dominant components included in the lime mud. Calcified cyanobacterial clusters are seen as a network of irregularly to radially distributed micritic filaments (Fig. 9A). The individual filaments consist of a central tubular void, up to $10 \mu \mathrm{m}$ in diameter, and an external coating of micrite $(1 \mu \mathrm{m})$ crystallites. The bench slope deposits are formed of well-defined, decimeter-thick, soft to indurated carbonate beds formed mainly of biomicrite (packstone and wackestone) in which the skeletal components, basically the same types observed within the platform carbonate beds, are oriented parallel to the bed surfaces. Fragments of calcified cyanobaterial clusters are clearly defined within the micrite groundmass (Fig. 9B). Thinner biomicrite laminae are locally recognized as a veneer on the single clinoform carbonate beds. The toe-of-slope carbonate beds exhibit fabrics that are similar to those observed in the slope beds. Carbonate forming a wedge at the side of the progradational bench also consists of packstone and wackestone containing charophyte stems and calcified cyanobacterial remains.

The mineralogy of the carbonate is only low-magnesium calcite $\left(\mathrm{MgCO}_{3}<2\right.$ $\mathrm{mol} \%$ ), with $\mathrm{Mg} / \mathrm{Ca}$ and $\mathrm{Sr} / \mathrm{Ca}$ ratios lower than 0.019 and 0.0020 , respectively (Bellanca et al. 1995). $\delta^{13} \mathrm{C}$ values from eight samples of the carbonate range from -5.6 to $-3.6 \%$, whereas $\delta^{18} \mathrm{O}$ values range from -6.9 to $-4.9 \%$ o (Bellanca et al. 1995).

Interpretation.-The carbonate textures with dominant micrite and variable amounts of skeletal components typical of freshwater conditions indicate deposition in a protected, low-energy lacustrine environment. The freshwater nature of the lake carbonate is also supported by mineralogy and geochemical data determined from the carbonates (Bellanca et al. 1995). Carbonate production was mostly biogenic, driven by extensive growth of charophytes on both the platform and the slope of the bench (cf. Murphy and Wilkinson 1980; Treese and Wilkinson 1982) and a significant population of cyanobacteria. The accumulation of carbonate in the horizontal bench platform resulted mainly from the breakdown of carbonate-encrusted stems of charophytes together with calcified cyanobacterial clusters, whereas in situ accumulation, followed by episodic resedimentation of these carbonate contributors, was the most effective mechanism of deposition in the bench slope. The origin of the micrite groundmass has not been investigated in detail, although our observations of the micrite under SEM suggest that most of the fine-grained carbonate could have been derived from disintegration of both encrusted charophyte stems (Dean 1981) and calcified cyanobacterial sheaths (Merz 1992).

The homogeneity of the carbonate textures across the bench shows that depositional conditions, both in terms of depth and energy under which carbonate accumulated, probably did not undergo significant changes. The internal pattern of carbonate strata in the bench indicates successive episodes of progradation of the carbonate platform basinward. The progradation took place throughout a generalized lake highstand, as evidenced by the aggradational and progradational geometries of the bench carbonates. The first clinoform set shows the lowest dip angles and covers 

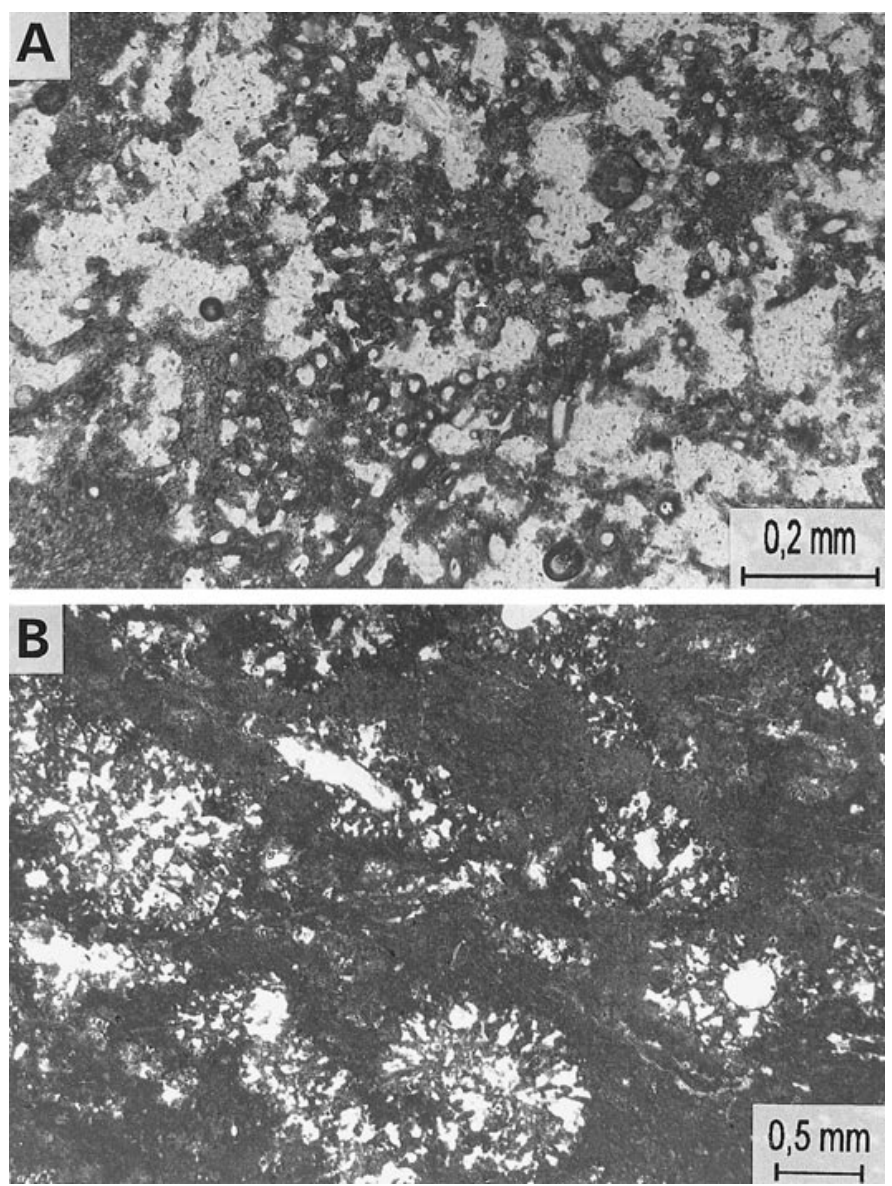

FIG. 9.-Photomicrographs showing specific microfacies aspects of the lake carbonate bench deposits: A) Detailed view of cyanobacterial micrite filaments from biomicrite that forms platform carbonate facies. The calcite crystals lie on the cyanobacterial sheaths. Both longitudinal and transverse sections of the calcified sheaths are illustrated. B) Cyanobacterial clusters forming a main component of the bench slope carbonate. The clusters exhibit a very porous, spongy internal structure with vague, irregular lamination. Some micrite tubes are locally recognizable. In some cases, the cyanobacterial clusters are developed surrounding Chara stems.

mudstone bay deposits that were related distally to deltaic topset sediments. We interpret these gently dipping carbonate beds as representative of an initial growth stage of the platform during the time that the fluvial deltaic systems retreated in response to lake-level rise. A combination of increasing accommodation space and proliferation of highly productive benthic plants under clearwater conditions resulted in the formation of the clinoform carbonate beds. Their gentle inclination was basically an adaptation to the geometry of the fluvial delta facies. Further lake-level rises resulted in the successive progradation of the second and third clinoform sets, which display increasing dip angles and correlate with tabular carbonate beds that accumulated on the bench platform. The sigmoid geometries shown by the clinoform sets at the edge of the platform fits well this progradational pattern of the bench.

The variation in the dip of the bench slope deposits could be related to minor drops in lake level. The deposition of the third clinoform set constituted the later stage of bench development. Onlap of carbonate beds at the base of the outer clinoform and further veneering by carbonate of the clinoform surface upward reflect disruption of the pattern of lake carbonate accumulation in front of the bench. Carbonate deposition at this stage of lake development was modified only by a flooding event marked by the input of clayey marlstone. The latter is interpreted as a distal terrigenous deposit related to the discharge of episodic streams entering the lake margin. The gentle dip angle of the clayey marlstone bed provides evidence of the lower gradient of the lake floor before the widespread development of palustrine conditions in the area.

\section{Basinal Deposits}

Description.-These deposits are not exposed in the cross section described above, but they crop out in several parts of the Rambla del Saltador. Where well exposed, an interfingering is observed with the toe-of-slope deposits of the adjacent benches. Basinal deposits consist of white, slightly indurated, tabular calcareous marlstone beds formed mainly of micrite with scattered ostracod shells and small monospecific (Hydrobia) gastropods. Lamination within these beds is roughly defined, and some signs of burrowing are observed. SEM observation of the marlstone reveals the presence of minute centric diatom frustules within the carbonate groundmass, which comprises a loosely packed aggregate of micron-size, rhombohedral calcite crystals and very minor clay particles.

Interpretation.-Most of the basinal material was due to settling of minute carbonate crystals formed by bio-induced chemical precipitation, which is typical of pelagic zones of freshwater perennial lakes (Eugster and Kelts 1983). The carbonate, with some contribution of clay particles and diatom frustules, accumulated at relatively shallow depth on the lake floor, as shown by moderate preservation of lamination and presence of minor bioturbation traces. The depth estimated for the deposition of the basinal sediments ranges from 5 to $10 \mathrm{~m}$. Under these conditions, permanent stratification of lake waters is improbable. Varve sedimentation, which is recognizable in other lake deposits of the basin (Calvo and Elizaga 1987; Calvo et al. 1998), is absent in the basinal deposits of the Rambla del Saltador area, also supporting the hypothesis that the lake water was not deep during development of the platform benches.

\section{Palustrine Carbonates and Marsh Deposits}

Description.-This facies association caps the lacustrine and deltaic deposits in the Rambla del Saltador area. The measured thickness of palustrine carbonates and marsh deposits is up to $15 \mathrm{~m}$. The association comprises mainly indurated carbonate beds, organic-rich marlstone, and sand-filled channels, the latter being restricted to troughs between adjacent carbonate benches. The palustrine carbonates comprise: (1) tabular, commonly root-bioturbated beds, ranging from a few centimeters to 70 $\mathrm{cm}$ thick, formed of pelmicrite and biomicrite with abundant charophyte stems and gyrogonites, gastropods, ostracods, and calcified cyanobacterial clusters; (2) strongly root-bioturbated biomicrite mounds; (3) oncoid- and intraclast-filled channels; and (4) thin (10-20 cm thick) tabular biomicrite beds consisting of a dense accumulation of encrusted charophyte stems. The interbedded dark, organic-rich marlstone deposits contain abundant gastropod shells (Planorbis, Hydrobia, Helix) and include some horizons of hydromorphic soils and thin layers formed of root mats. Irregularly distributed patches of reddened marlstone, interpreted to be a result of spontaneous burning of the organic-rich deposits, are locally observed. Sand-filled channels, ranging from 5 to $30 \mathrm{~m}$ in width and up to 1.4 deep, show lateral accretion and abundant reactivation surfaces. The channel fills are fine- to medium-grained litharenites with abundant phytoclasts and some oncoids.

Interpretation.-Both carbonate and organic-rich marlstone deposits are characteristic of a palustrine environment, i.e., shallow lake areas subjected to episodic or periodic fluctuation of water level, where areas of carbonate deposition are coeval and/or succeed marshes with rather rapid accumulation of organic matter. These depositional features fit well the "low-gradient ramp-low energy" model of Platt and Wright $(1991,1992)$. In the Rambla del Saltador, evidence of subaerial exposure of carbonate sediments is shown mainly by extensive root bioturbation leading to the development of prismatic structures and carbonate mounds (Freytet 1984; Calvo et al. 1985; Alonso-Zarza et al. 1992). Carbonate production was related mainly to extensive growth of charophytes and cyanobacteria, as well as gastropod and ostracod benthic faunas living in freshwater. Pedogenic modification linked to lowstand periods is also recorded in the organic-rich marlstone in the form of hydromorphic soils. The presence of sand-filled channels in troughs between adjacent carbonate benches suggests that these depressed areas were favorable sites for meandering fluvial streams to reach the margins of the shallow lake environment.

\section{SEDIMENTARY MODEL}

In this section we present an integrated model for the development of lake carbonate deposits and associated terrigenous sediments in the Rambla del Saltador area. From the selected example described above, a close relationship between the emplacement of a fluvially dominated delta and the growth of a lake carbonate bench can be deduced. The same relationship can be also observed at several other locations throughout the study area (Fig. 3).

\section{Development and Characteristics of the Fluvially Dominated Deltas}

The alternating terrigenous and carbonate deposits exposed along the Rambla del Saltador are a part of a thicker (up to $150 \mathrm{~m}$ ) sedimentary complex restricted to the northern part of the Las Minas Basin (Fig. 1B). The position of this terrigenouscarbonate stratigraphic unit suggests that during the later stages of basin infill (Upper Turolian) the northern part of the basin behaved as a rapidly subsiding trough related to fault reactivation of the basin margin. In this setting, a fluvial system flowing 
A

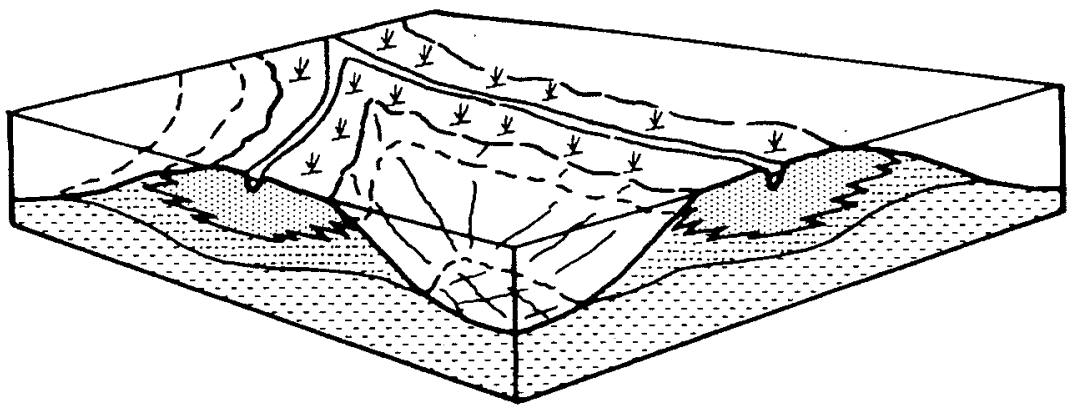

B

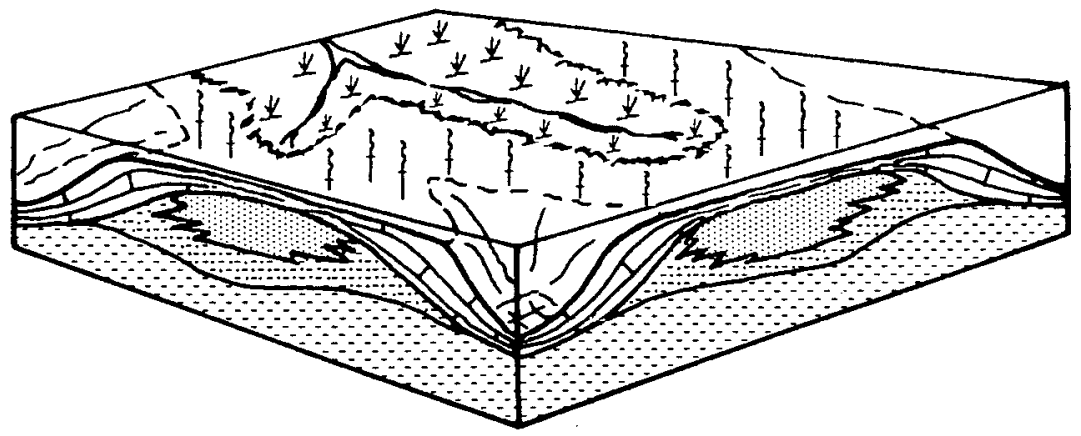

C

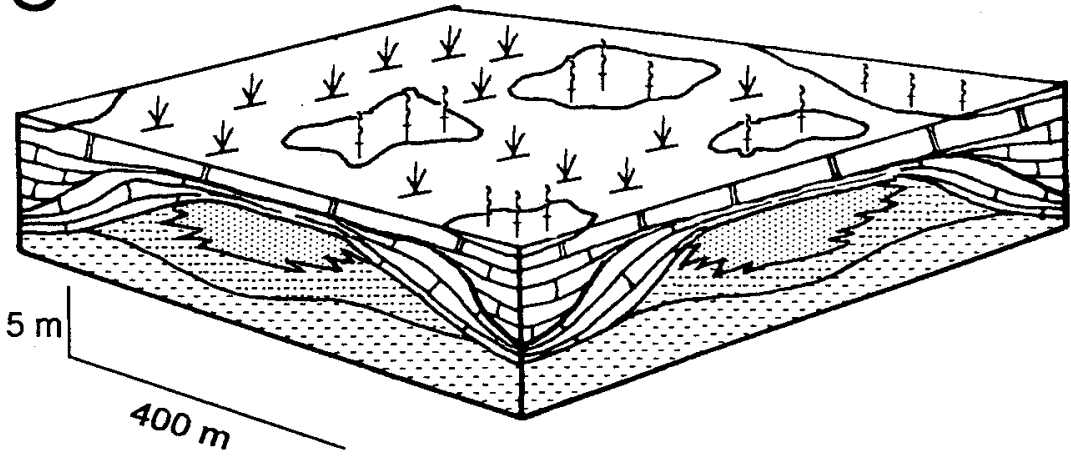

Palustrine limestones

$\square$ Lacustrine limestones
Topset and foreset terrigenous deposits

Bottomset and offshore marlstones
FIG. 10.-Idealized paleogeographic sketches showing evolution of fluvially dominated deltas and associated carbonate platforms in the Rambla del Saltador area. A) Development of the fluvially dominated shallow deltas according to a "birdfoot" pattern; estimated depth of lake floor is $3-5 \mathrm{~m}$ as deduced from thickness of Gilbert-type foreset units. B) Development of freshwater lake carbonate benches fringing the deltas; estimated depth of lake floor is $<8 \mathrm{~m}$. C) Final stage showing generalized flooding of the area by lake waters and development of a low-gradient (ramp) carbonate lake system overlying the carbonate benches. The scale in the drawing is approximate and indicative of the size of the deltas and associated carbonate benches; it does not reflect distance between the deltaic bodies. from the south (and southeast?) toward the north and northwest discharged in the Rambla del Saltador area through several distributaries, forming a "birdfoot" delta plain (type D feeder system of Postma 1995). The spatial distribution of the main sandstone deposits that mark the locations of the distributary mouth bars and/or delta-front deposits delineates a digitate geometry (Fig. 10A), with streams flowing predominantly toward the north and northwest. Distinction between north-flowing distributaries and those discharging more to the west, toward more open lake areas, is significant because the carbonate benches that developed on the delta fingers display some differences in depositional features (see comments below).

The deltaic deposits show typical Gilbert-type profiles (Gilbert 1885; Flores 1990) formed of (i) bottomset, marly and silty horizontal beds that accumulated in a prodelta environment, (ii) steeply inclined foreset beds (delta-front environment), and (iii) overlying topset beds. The overall geometry of these deposits is probably the result of progradational streams of the delta-plain distributary channels formed at the points where these channels intersected the lake margin. As observed in some sections, episodic drops in lake level could have resulted in the incision of proximal foreset deposits by the progradational channels. The thickness of the foreset units can be used as a good indicator of the depth of the lake basin (Smoot and Lowenstein 1991; Postma 1995). In the Rambla del Saltador deltas, the measured thicknesses of the foresets hardly exceed $3 \mathrm{~m}$, which clearly indicates the relatively shallow character of the lake at the time the deltas were formed. This interpretation is compatible with the category of shallow-water deltas (water depths of the order of some tens of meters) with wider-spaced, highly stable channels proposed by Postma (1990, 1995). This type of delta is characterized by a low ratio of bedload to total load, which fits well with the localized accumulations of medium- to coarse-grained sandstone and the widespread distribution of mudstone in the Rambla del Saltador area.

\section{Growth of the Lake Carbonate Benches}

Development of the carbonate benches started when terrigenous deltaic deposition at the lake margin became progressively reduced as a result of relative rise of lake 
level and flooding of the delta topset surface. Under these conditions of reduced terrigenous input and increase of the available accommodation space adjacent to the delta bodies, high productivity by shallow-water benthic plants and cyanobacteria resulted in buildup of the shore zone and its progradation into the lake (Platt and Wright 1991). Lateral to the deltas, the carbonate deposits rapidly thicken, providing evidence of the geomorphological constraints on carbonate bench development (Fig. 10B). The architecture of the carbonate benches reflects episodic, stepwise progradation of the lake carbonate deposits. Growth of the carbonate bench took place through three successive sets of clinoforms, which overall show a sigmoid-oblique pattern with offlap upper boundary relationships (Bosellini 1984; Friedman et al. 1992). These offlap relationships resulted from slow though continuous lake-level rise. Differences in slope between successive clinoform sets were caused by episodic stabilization of the growth of the carbonate platforms. This fits well the basic features of the offlap model suggested by Tucker and Wright (1990), in which the rimmed platform margin progrades basinwards because of stillstand or slow lakelevel rise and an overproduction of carbonate at the platform edge. In our case, high carbonate production was related mainly to the development of meadows of charophytes and cyanobacterial mats, which became rapidly encrusted by carbonate. Reworking, essentially by waves probably generated during episodic storms, of the benthic flora at the platform rim was probably the main mechanism for producing the periplatform sloping strata, although in situ growth of charophytes and cyanobacteria on the upper slope surfaces might also account for significant carbonate production. The effect of reworking is more pronounced in benches that faced more open lake areas, i.e., to the west of the region. In this setting, many carbonate beds forming the benches commonly display wave-ripple bedding and local small-scale hummocky cross-stratification, both features indicative of higher energy conditions.

Onlap relationships of lacustrine carbonate beds on the most distal clinoform of the bench indicate the cessation of progradation of the carbonate platform. The change in the progradation pattern was probably due to a new lake-level rise, resulting in an enlargement of the area flooded by lake water. This is supported by the fact that the infill of the "residual basins" in front of the carbonate benches was by carbonate with fabrics similar to those of the carbonate platform bench deposits; the basal onlapping carbonates are succeeded by carbonate beds that eventually veneered the bench slope beds and finally overlaid the platform benches. This infill pattern shows the evolution from a steep-gradient (bench) to a low-gradient (ramp) carbonate lake margin (Fig. 10C).

\section{DISCUSSION}

\section{Comparison with Modern Examples of Lake Carbonate Benches}

The facies model for carbonate lakes with high-gradient, bench type margins developed under low-energy conditions (the steep-gradient "bench" margins-low energy model of Platt and Wright 1991) was proposed following observations of the depositional pattern exhibited by progradational marl benches in several small temperate lakes in Michigan (Murphy and Wilkinson 1980; Treese and Wilkinson 1982). This facies model has been supplemented by a large-scale example from the Lower Cretaceous Peterson Limestone of Wyoming and Idaho (Glass and Wilkinson 1980), which displays lake carbonate facies that could be taken as an ancient analogue for temperate-region marl basins (Platt and Wright 1991). The Upper Miocene Rambla del Saltador deposits described in this paper provide a good case study of progradational marl benches in the rock record because they show striking similarities to, but also some significant variations (see comments below) from, those documented from modern lake systems. First, the lake carbonate benches from Rambla del Saltador were of size, i.e., widths of a few tens of meters and thicknesses ranging from 5 to $10 \mathrm{~m}$, similar to that of modern examples in marl lakes. In Littlefield Lake, Murphy and Wilkinson (1980) reported the width of the gently inclined $\left(\sim 2^{\circ}\right)$ bench platform as ranging from 5 to $20 \mathrm{~m}$, which is of the same order of magnitude as that observed in Rambla del Saltador. The slope of the progradational bench in Littlefield Lake reaches a maximum angle of about $30^{\circ}$, which is closely comparable to the maximum angle of up to $28^{\circ}$ in the outermost progradational beds of the lake carbonate benches of Rambla del Saltador.

Depositional conditions of progradational marl benches in Littlefield Lake, and probably in Sucker Lake (Treese and Wilkinson 1982), serve as a good reference for those that can be inferred from the Rambla del Saltador deposits. In Littlefield Lake, the bench platform lies in water depths of less than $1.5 \mathrm{~m}$ and the lake floor is more than $20 \mathrm{~m}$ deep (Murphy and Wilkinson 1980). The depth of the basinal deposits in Rambla del Saltador probably did not exceed $10 \mathrm{~m}$, using a conservative estimate based on the difference in height between the edge of the platform benches and the toe-of-slope sediments. Shallow-water conditions on the bench platform can be inferred from the components of the carbonate platform deposits, as well as by geometric relationships between the well-bedded, tabular carbonates that accumulated in medial to distal parts of the platforms and the reworked, carbonate-filled channels that formed on top of the delta top. The latter were deposited by episodic streams in very shallow water. The widespread presence of encrusted charophyte stems, gyrogonites, and calcified cyanobacterial clusters within the bench platform carbonate of Rambla del Saltador also supports a shallow depositional environment (Dean and Fouch 1983). Fragments of encrusted Chara stems are reported as a dominant component of carbonate bench facies, especially in the bench slope units of Littlefield Lake (Murphy and Wilkinson 1980) and in both the bench platform and slope deposits of Sucker Lake (Treese and Wilkinson 1982). In addition to these examples, the important contribution of charophyte stems and oogonia to littoral hard-water lake carbonate sediments has been widely recognized elsewhere (e.g., Terlecky 1974; Dean 1981; Tucker and Wright 1990). Besides the presence of abundant fragments of encrusted Chara, bench platform carbonate of Littlefield Lake contains algal pisoliths (oncoliths), which are a major component of the sediment that accumulates in this environment (Jones and Wilkinson 1978). We have not found such well-developed organic structures in the carbonate sediments of Rambla del Saltador. The only comparable comparable components are calcified cyanobacterial clusters that, with encrusted charophyte stems, form bulk of the lake bench carbonate deposits. Moreover, no clear distinction of well-defined carbonate facies has been recognized in the Rambla del Saltador, except for bench platform and bench slope carbonates. There the difference in lithofacies between the two depositional environments is marked by the predominance of reworked fragments of charophyte stems and calcified cyanobacterial clusters that are arranged parallel to the inclined bed surfaces at the bench slope, whereas the bench platform deposits do not exhibit such a well-laminated internal structure. This is in contrast with the subdivision of the Littlefield Lake marl bench deposits into six facies that form an overall coarsening-upward sequence (Murphy and Wilkinson 1980).

In view of the strong similarities both in the geometry and composition of their deposits, the lake carbonate benches of Rambla del Saltador can be regarded as typical products of sedimentation in temperate hard-water (waters supersaturated with respect to $\mathrm{CaCO}_{3}$ ) lakes where assimilation of $\mathrm{CO}_{2}$ by photosynthesis is the most important mechanism of $\mathrm{CaCO}_{3}$ precipitation (Dean 1981). In this setting, the rate of $\mathrm{CaCO}_{3}$ accumulation is greater in the littoral zones than in the deeper ones. The Rambla del Saltador deposits, which developed in a lake located at $38-39^{\circ}$ latitude (similar to the present day; Smith 1996), and surrounded by a limestone watershed, are a good example of the differential growth rate of highly productive, littoral lake zones leading to the building of carbonate benches in a marl lake setting. However, specific constrains, notably the pattern of lake-level evolution and the topographic control exerted by preexisting sediment bodies, on the development of the carbonate benches introduce some variations that could be used for refining the current facies model for this type of lake sedimentation.

\section{Contribution to the Carbonate Bench Lake-Margin Facies Model}

Despite the strong similarities between the lake carbonate bench deposits of Rambla del Saltador and those documented from several modern North American lakes, some differences in growth pattern can be outlined (Fig. 11). The first relevant point is that the installation of the carbonate benches of Rambla del Saltador was closely related to the convex-upward morphologies of the deltaic systems that had previously accumulated at the lake margin. This picture is notably different from that described from modern marl lakes, where bench development does not seem to have been constrained by any geomorphic feature. Interpretation of lake carbonate benches in other ancient or modern settings should consider this aspect.

A second point concerns the progradational pattern observed in the Rambla del Saltador carbonate benches. In contrast with the regular progradation of the benches described in modern marl lakes, the clinoforms of Rambla del Saltador show marked discontinuous variations in slope angles throughout the stepwise progradation of the platform. Moreover, the carbonate beds display offlap relationships. Both features reflect growth of the bench as a response to slow, episodic lake-level rise in the absence of significant terrigenous supply. Accordingly, the discontinuous upbuilding and outbuilding pattern shown by the carbonate benches described in this study could be considered a reference for the evaluation of other ancient, and perhaps modern, lacustrine carbonates.

Finally, the Rambla del Saltador deposits provide an excellent example of the transition from lake carbonate benches into a low-gradient ( environment. This evolution from progradational marl benches to shallow, even subaerially deposited facies (calcareous peat) has also been observed in Littlefield Lake (Murphy and Wilkinson 1980). Sediments from Sucker Lake show a similar regressive trend, although in that case the partial infilling of the lake resulted from a huge accumulation of deltaic phytoclast deposits entering the lake basin (Treese and Wilkinson 1982). Nevertheless, detailed observation of the geometries of the Upper Miocene deposits of Rambla del Saltador reveals a distinct regressive pattern of the lake-margin facies when compared with that described from modern lakes. In our example, the carbonate bench ended its growth when lake level was still relatively high but stable. Under these stillstand conditions the infilling of the "residual" lake basin developed in front of the bench was rapid, leading to a progres- 
A

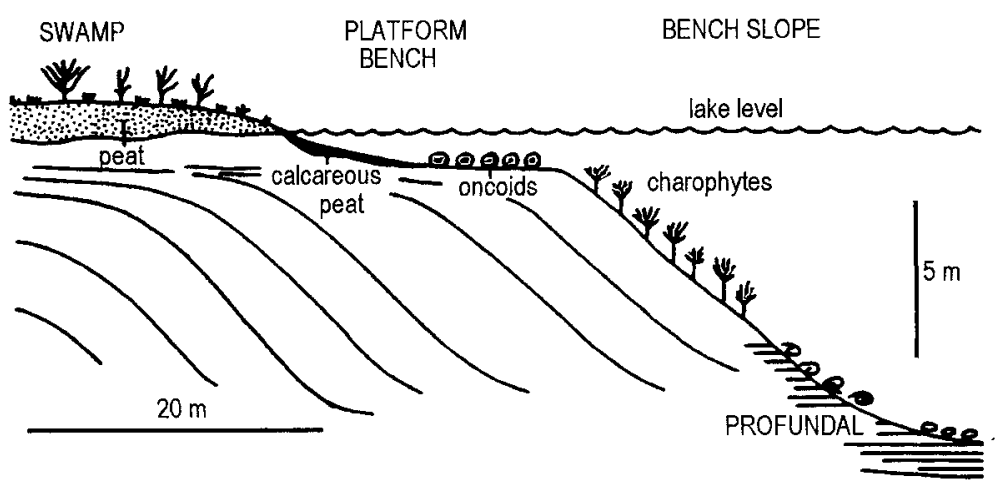

B

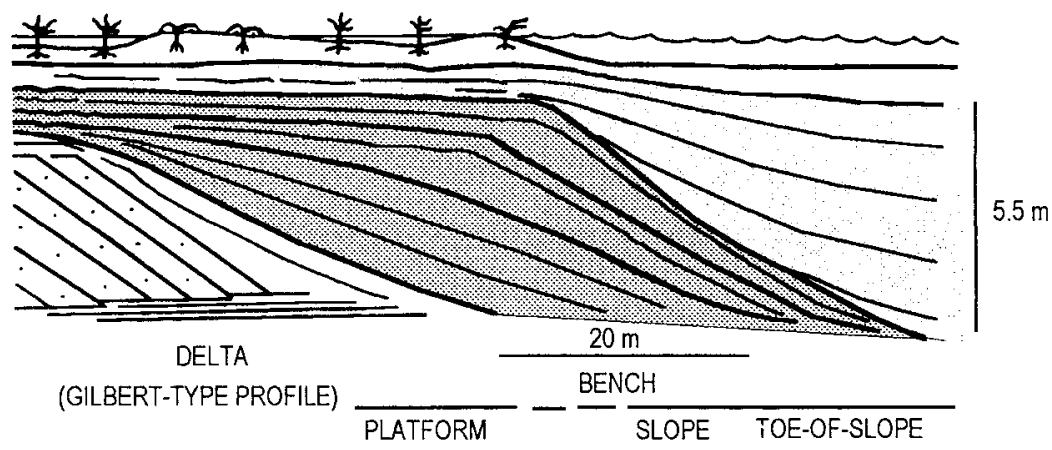

FIG. 11.-Comparison with the carbonate bench facies model derived from recent marl lakes (Murphy and Wilkinson 1980; Treese and Wilkinson 1982); A) Figure modified from Platt and Wright 1991) and B) the case study of carbonate benches from Rambla del Saltador. Main differences between the two models relate to the continuous vs. discontinuous progradational pattern of the bench, the evolution from bench to ramp, and the topographic control of previous depositional systems on the development of the carbonate benches. sive decrease of the gradient of the lake floor and eventually to extensive shallow lake (ramp) conditions. The resulting pattern is thus defined by a package of palustrine deposits that transitionally overlie the carbonate benches, which is in contrast with the toplap or truncation geometrical relationships deduced from modern lakes.

\section{CONCLUSIONS}

Lake carbonate deposits in the Upper Miocene succession of the Las Minas Basin provide new insights into the development of low-energy, steep-gradient carbonate lake margins previously modeled from modern temperate marl lakes. In our case study, the lake carbonate benches are closely associated with fluvially dominated deltas that exhibit Gilbert-type profiles. The association of the two depositional systems clearly indicates that the initiation of the carbonate benches was favored by the convex-up delta morphologies as enough accommodation space was created adjacent to the delta bodies. Moreover, the lake carbonate bench deposits display a discontinuous progradational pattern outlined by offlap relationships of the slope and platform carbonate beds forming the bench. This progradational pattern is inferred to be related to a relatively slow but continuous lake-level rise. Carbonate production on the bench platform was due mainly to the development of meadows of charophytes and cyanobacterial mats with some contribution from gastropod and ostracod shells. The bench slope beds consist mainly of reworked carbonate fragments, although a significant contribution of in situ carbonate producers is also envisaged. The carbonate components of the Rambla del Saltador benches show strong similarities to those forming marl benches in modern temperate lakes. In addition, the Upper Miocene carbonate benches are of similar size to their modern counterparts, such that depositional conditions, i.e., water depths on the platform and at toes of the benches, can be related to those of the ancient sediments. However, despite the observed similarities, some significant differences arise when the ancient example is compared to the modern ones. The main differences concern the discontinuous progradational pattern of the carbonate benches and, importantly, the evolutionary trend that leads to cessation of bench development and further sedimentary infilling of the lake basin. In this respect, the Rambla del Saltador deposits provide a very good illustration of the transition from a bench-type to a ramp-type carbonate lake margin, which contributes to a wider view of how carbonate lake margins can develop under different geological conditions.

\section{ACKNOWLEDGMENTS}

The authors would especially like to thank Joan Rosell, who helped decisively in our initial understanding of the terrigenous depositional systems of the study area. At that time (1989-1990) we were collaborating actively with our friend Emilio Elizaga, who unfortunately died some time later. We are also indebted to Miguel A. Rodríguez Pascua for his valuable comments on the tectonics of the region as well as in furnishing some computer-based graphics. Computer management was also supported by Cristina Ferrer and Lluis Duocastella. We thank Ramón Mas and Alfredo Arche for their suggestions on an earlier version of the manuscript. Blas L. Valero-Garcés, Michael R. Talbot, and the JSR Associate Editor Robin W. Renaut are thanked for their constructive reviews of the manuscript. The research was supported by Commission of Science and Technology of Spain (CICYT) through Project AMB94-0994.

\section{REFERENCES}

Alonso-Zarza, A.M., Calvo, J.P., and García del Cura, M.A., 1992, Palustrine sedimentation and associated features-grainification and pseudo-microkarst-in the Middle Miocene (Intermediate Unit) of the Madrid Basin, Spain: Sedimentary Geology, v. 76, p. 43-61.

Armenteros, I., Daley, B., and García, E., 1997, Lacustrine and palustrine facies in the Bembridge Limestone (late Eocene, Hampshire Basin) of the Isle of Wight, southern England: Sedimentary Geology, v. 128, p. 111-132.

Bellanca, A., Calvo, J.P., Censi, P., Elizaga, E., and Neri, R., 1989, Evolution of lacustrine diatomite carbonate cycles of Miocene age, southeastern Spain: Petrology and isotope geochemistry: Journal of Sedimentary Petrology, v. 59, p. 45-52.

Bellanca, A., Calvo, J.P., Neri, R., and Mirto, E., 1995, Lake margin carbonate deposits of Las Minas Basin, Upper Miocene, southeastern Spain. A sedimentological and geochemical approach to the study of lacustrine and lacustrine paleoenvironments: Mineralogica et Petrographica Acta, v. 38, p. 113-128.

Bellon, H., Bizon, G., Calvo, J.P., Elizaga, E., Gaudant, J., Lopez-Martínez, N., and Usera, J., 1980, Le volcan du Cerro del Monagrillo (Prov. de Murcia): Age absolu et corrélations avec les sédiments neogènes du bassin de Hellín (Espagne): Academie des Sciences, Paris, Comptes Rendus, Série 2, Mécanique Physique, Chimie, Sciences de l’Univers, Sciences de la Terre, v. 292, p. 1035-1038.

Bosellin, A., 1984, Progradation geometries of carbonate platforms: examples from the Triassic of the Dolomites, northern Italy: Sedimentology, v. 31, p. 1-24. 
Brown, R.E., AND WiLkinson, B.H., 1981, The Draney Limestone: Early Cretaceous lacustrine carbonate deposition in western Wyoming and southeastern Idaho: University of Wyoming, Contributions to Geology, v. 20, p. 23-31.

Cabrera, L., Colombo, F., and Robles, S., 1985, Sedimentation and tectonics interrelationships in the Paleogene marginal alluvial systems of the Ebro Basin. Transition from alluvial to shallow lacustrine environments: International Association of Sedimentologists, 6th European Regional Meeting, Lleida, Excursion Guidebook, p. 395-494.

Calvo, J.P., and Elizaga, E., 1987, Diatomite deposits in southeastern Spain: geologic and economic aspects. Instituti Geologici Publici Hungarici, Annales, v. 70, p. 537-543.

Calvo, J.P., And Elizaga, E., 1994, The Cenajo and Las Minas-Camarillas basins (Miocene), southeastern Spain, in Gierlowski-Kordesch, E., and Kelts, K., eds., Global Geologic Record of Lake Basins, vol. 1: Cambridge, U.K., Cambridge University Press, p. 319-324.

Calvo, J.P., Hoyos, M., and García del Cura, M.A., 1985, Mud-mound structures in shallow lacustrine sediments, Middle Miocene, Madrid Basin, Spain: International Association of Sedimentologists, 6th European Regional Meeting, Lleida, Spain, Abstracts, p. 539-542.

Calvo, J.P., Rodríguez-Pascua, M.A., Martín-Velazquez, S., De Vicente, G., and JiménezSÁNCHEZ, S., 1998, Microdeformation of lacustrine laminite sequences from Late Miocene formations of SE Spain: an interpretation of loop bedding: Sedimentology, v. 45, p. 279292.

Coleman, J.M., and Gagliano, S.M., 1965, Sedimentary structures: Mississippi River deltaic plain, in Middleton, G.V., ed., Primary Sedimentary Structures and Their Hydrodynamic Interpretation: Society of Economic Paleontologists Mineralogists, Special Publication 12, p. $133-148$

DEAN, W.E., 1981, Carbonate minerals and organic matter in sediments of modern north temperate hard-water lakes, in Ethridge, F.G., and Flores, R.M., eds., Recent and Ancient Nonmarine Depositional Environments: Models for Exploration: Society of Economic Paleontologists Mineralogists, Special Publication 31, p. 213-231.

Dean, W.E., AND Fouch, T.D., 1983, Lacustrine Environment, in Scholle, P.A., Bebout, D.G., and Moore, C.H., eds., Carbonate Depositional Environments: American Association of Petroleum Geologists, Memoir 33, p. 96-130.

Donaldson, A.C., Martin, R.H., and Kanes, W.H., 1970, Holocene Guadalupe delta of Texas Gulf Coast, in Morgan, J.P., ed., Deltaic Sedimentation, Modern and Ancient: Society of Economic Paleontologists Mineralogists, Special Publication 15, p. 107-137.

Elizaga, E., 1994, Análisis de facies sedimentarias y petrología de los depósitos lacustres de edad Neógeno superior de la Zona Prebética, Albacete, España: Instituto de Estudios Albacetenses, Albacete, Spain, 216 p.

Eugster, H.P., And Kelts, K., 1983, Lacustrine chemical sediments, in Goudie, A.S,. and Pye, K., eds., Chemical Sediments and Geomorphology: London, Academic Press, p. 321-368.

FISK, H.N., 1961, Bar-finger sands of the Mississippi delta, in Peterson, J.A., and Osmond, J.C., eds., Geometry of Sandstone Bodies: Tulsa, Oklahoma, American Association of Petroleum Geologists, p. 29-52.

FLoRES, R.M., 1990, Transverse and longitudinal Gilbert-type deltas, Tertiary Coalmont Formation, North Park Basin, Colorado, USA, in Colella, A., and Prior, D.B., eds., CoarseGrained Deltas: International Association of Sedimentologists, Special Publication 10, p. 223-233.

FREYTET, P., 1984, Les sédiments lacustres carbonatés et leurs transformations par émersion et pédogenèse. Importance de leur identification pour les reconstructions paléogéographiques: Bulletin des Centres de Recherche Exploration-Production Elf-Aquitaine, v. 8, p. 223-247.

Freytet, P., and Plaziat, J.C., 1982, Continental carbonate sedimentation and pedogenesis-
Late Cretaceous and Early Tertiary of southern France: Stuttgart, Schweizerbart, Contributions to Sedimentology, v. 12, 213 p.

Friedman, G.M., Sanders, J.E., and Kopaska-Merkel, D.C., 1992, Principles of Sedimentary Deposits; Stratigraphy and Sedimentology: New York, Macmillan, $717 \mathrm{p}$.

GilBerT, G.K., 1885, The topographic features of lake shores: U.S. Geological Survey, Fifth Annual Report, p. 69-123.

Glass, S.W., AND Wilkinson, B.H., 1980, The Peterson Limestone-Early Cretaceous lacustrine carbonate deposition in western Wyoming and southeastern Idaho: Sedimentary Geology, v. 27, p. $143-160$.

Gould, H.R., 1970, The Mississippi delta complex, in Morgan, J.P., ed., Deltaic Sedimentation, Modern and Ancient: Society of Economic Paleontologists Mineralogists, Special Publication 15 , p. 3-47.

JoNES, F.G., AND WILKINSON, B.H., 1978, Structure and growth of lacustrine pisoliths from recent Michigan marl lakes: Journal of Sedimentary Petrology, v. 48, p. 1103-1110.

Lowe, D.R., 1982, Sediment gravity flows: II. Depositional models with special reference to the deposits of high-density turbidity currents: Journal of Sedimentary Petrology, v. 52, p. 279-297.

Merz, M.U.E., 1992, The biology of carbonate precipitation of Cyanobacteria: Facies, v. 26, p. $81-102$.

MuRPhy, D.H., AND WiLKInSON, B.H., 1980, Carbonate deposition and facies distribution in a central Michigan marl lake: Sedimentology, v. 27, p. 123-135.

Orton, G.J., and Reading, H.G., 1993, Variability of deltaic processes in terms of sediment supply, with particular emphasis on grain size: Sedimentology, v. 40, p. 475-512.

PlatT, N.H., AND WRIGHT, V.P., 1991, Lacustrine carbonates: facies models, facies distributions and hydrocarbon aspects, in Anadón, P., Cabrera, L., and Kelts, K., eds., Lacustrine Facies Analysis: International Association of Sedimentologists, Special Publication 13, p. 57-74.

Platt, N.H., AND Wright, V.P., 1992, Palustrine carbonates and the Florida Everglades: towards an exposure index for fresh-water environment?: Journal of Sedimentary Petrology, v. 62 , p. $1058-1071$.

Postma, G., 1990, Depositional architecture and facies of river and fan deltas: a synthesis, in Colella, A., and Prior, D.B., eds., Coarse-Grained Deltas: International Association of Sedimentologists, Special Publication 10, p. 13-27.

Postma, G., 1995, Causes of architectural variation in deltas, in Oti, M.N., and Postma, G., eds., Geology of Deltas: Rotterdam, A.A. Balkema, p. 3-16.

Sмiтh, A.G., 1996, Cenozoic latitudes, positions and topography of the Iberian Peninsula, in Friend, P.F., and Dabrio, C.J., eds., Tertiary Basins of Spain: The Stratigraphic Record of Crustal Kinematics: Cambridge, U.K., Cambridge University Press, p. 6-8.

Smoot, J.P., and Lowenstein, T.K., 1991, Non-marine evaporites, in Melvin, J.L., ed., Evaporites, Petroleum and Mineral Resources: Amsterdam, Elsevier, p. 189-347.

TERLECKY, P.M., 1974, The origin of a Late Pleistocene and Holocene marl deposit: Journal of Sedimentary Petrology, v. 44, p. 456-465.

Treese, K.L., AND Wilkinson, B.H., 1982, Peat-marl deposition in a Holocene paludal-lacustrine basin-Sucker Lake, Michigan: Sedimentology, v. 29, p. 375-390.

TuCKer, M.E., AND Wright, V.P., 1990, Carbonate Sedimentology: Oxford, U.K., Blackwell, $482 \mathrm{p}$

WelLs, N., 1983, Carbonate deposition, physical limnology and environmentally-controlled chert formation in Palaeocene-Eocene Lake Flagstaff, central Utah: Sedimentary Geology, v. 35 , p. $263-296$.

WRIGHT, L.D., 1977, Sediment transport and deposition at river mouths: a synthesis: Geological Society America, Bulletin, v. 88, p. 857-868.

Received 5 August 1998; accepted 29 January 1999. 